\title{
SOLA PULCHERRIMA SUPER SOLEM - "NAD SLOŃCE I NAD MIESIĄC CUDNIEJSZA" (MODLITWA MARYJNA Z MODLITEWNIKA GERTRUDY I MODLITEWNIKA NAWOJKI)
}

Nowa i krytyczna edycja zbioru modlitw, związanych z Gertrudą Mieszkówną (ok. 1025-1108), polską królewną żoną wielkiego księcia kijowskiego Izjasława ${ }^{1}$, poprzedzona wydaniem polskiego ich przekładu ${ }^{2}$, ożywiła zainteresowania tym niezwykłym świadectwem piśmiennictwa i religijności XI w. Burzliwe i skomplikowane koleje życia Gertrudy, jej męża oraz ukochanego syna JaropełkaPiotra, którego osoba stanowi ważny przedmiot modłów księżny, doczekały się osobnej monografii ${ }^{3}$. Szczegółowe opracowanie zyskało ponadto pięć miniatur dołączonych do modlitw ${ }^{4}$. Niezwykłe bogactwo problemów skupionych wokół modlitewnika pobudza do dalszych rozważań. Jednym z nich są współbrzmienia ikonograficzne modlitw tak z towarzyszącymi im miniaturami jak i ze współczesnymi Gertrudzie dziełami sztuki - na zachodnich i wschodnich obszarach jej życia, od Nadrenii, gdzie uzyskała wyksztalcenie, po Ruś Kijowska, gdzie spędziła większość życia. Treści modlitw ożywają w nich, nabierają kolorów i kształtów właściwych epoces.

Modlitwy Gertrudy, według najświeższego podziału w liczbie 95, posiadają w przeważającej część charakter teocentryczny i chrystocentryczny, toteż wątkowi maryjnemu, uznanemu ponadto za konwencjonalny, poświęcono dotąd niewiele

\footnotetext{
${ }^{1}$ Modlitwy księżnej Gertrudy z Psatterza Egberta z Kalendarzem (Liber precum Gertrudae ducissae e Psalterio Egberti cum Kalendario). Wydanie M. H. Malewicz i B. Kürbis, opracowanie B. Kürbis, wspólpraca D. Leśniewska i P. Stróźyk, „Monumenta Sacra Polonorum” t. II, Kraków 2002 (oryginalny rękopis przechowywany jest w Museo Archeologico Nazionale w Cividale del Friuli we Włoszech jako cod. CXXXVI).

${ }^{2}$ Modlitwy księżnej Gertrudy z Psalterza Egberta w Cividale, przekł. i oprac. B. Kürbis, Kraków 1998.

${ }^{3}$ T. M i c h a łow s k a, Ego Gertruda. Studium historycznoliterackie, Warszawa 2001.

${ }^{4}$ M. S m o r ą g - R ó ż y c k a, Bizantyńsko-ruskie miniatury Kodeksu Gertrudy. O kontekstach ideowych i artystycznych sztuki Rusi Kijowskiej XI wieku, Kraków 2003.

${ }^{5}$ Tą problematyką zajęlam się w dwóch studiach - K. T a r g o s z, Modlitwy Gertrudy na tle ówczesnej mistycznej ikonosfery, [w:] Polska literatura mistyczna (w druku); t a ż, Treści maryjne w Modlitewniku Gertrudy i ich wspótbrzmienia ikonograficzne [w:] Specyficzne cechy religijności kobiet na ziemiach polskich (w druku). Niniejszy tekst jest skróconą wersją drugiego z nich, ale z dodaniem omówienia modlitwy z Modlitewnika Nawojki.
} 
uwagi ${ }^{6}$. Tylko nieznaczna część modlitw adresowana jest specjalnie do Marii, aniołów i świętych, chociaż i w innych modlitwach występują wplecione do nich aluzje i wezwania. Tak też w pięciu modlitwach znajdujemy odniesienia do roli wstawienniczej Marii, pośredniczki przed Bogiem, mającym szczególny wzgląd dla jej zasług - „per intercessionem sancte Marie” (3), „per intercessionem sancte Marie genitricis tue"(15), „per ... eiusque genitricis intercessionem”(18), ,per merita sancte et immaculate uirginis Marie"(21), ,interueniente sancta Maria" $(74)^{7}$. Maria wymieniana jest tu przed aniołami oraz ,wszystkimi świętymi”, wspominanymi przeważnie ogólnie, a wyjątkowo także imiennie, jak w wypadku św. Heleny (15). Są to modlitwy z prośbami w różnych intencjach - o szczęśliwą śmierć, miłosierdzie, pomyślność dla syna. Modlitwę za zmarłych kończy bezpośrednie wezwanie do wstawiennictwa za ich dusze u Boga (,Sancta Maria, perpetua Uirgo, intercede pro animabus omnium fidelium defunctorum ..." - 40).

W świecie wschodniego chrześcijaństwa miala Gertruda możność oglądania niezwykle częstego tu wyobrażenia typu Deesis - modlitwy wstawienniczej Marii i św. Jana Chrzciciela, stojących po bokach tronującego Chrystusa, z dłońmi wyciagniętymi w geście prośby o wysłuchanie. I tak np. zajmując miejsce na emporze przeznaczonej dla rodziny książęcej w katedrze Św. Sofii w Kijowie, widziała je naprzeciw siebie, $w$ formie trzech mozaikowych tond $z$ popiersiami (o średnicy $1 \mathrm{~m}$ ), usytuowanymi na łuku obramiającym główną apsydę, zwanym łukiem triumfalnym ${ }^{8}$. Wspaniałą dekorację mozaikową gómych partii budowli wykonali sprowadzeni z Bizancjum artyści w latach 1043-1046, a więc w początkowym okresie pobytu Gertrudy na Rusi.

Cztery modlitwy zwrócone są bezpośrednio i w całości do Marii. Dwie $\mathrm{z}$ nich posiadają charakter pochwalno-błagalny, dwie zaś w całości pochwalny. Maryjne modlitwy pierwszego typu $(85,87$ - ta ostatnia najdłuższa w całym zbiorze) rozpoczynają się partiami pochwalnymi, ale wypełnione są przede wszystkim prośbami, skoncentrowanymi, tak jak i wiele innych modlitw, na osobie syna. Nazywany ,jedynym" (unicus filius meus), w sensie ,wyjątkowy”, ,umiłowany" (Gertruda miala co najmniej dwóch synów), wielokrotnie wymieniony jest imiennie jako Piotr. Nosił on rodzime, dynastyczne imię Jaropełk, ale zgodnie z ówczesnym zwyczajem panującym na Rusi, posiadał także imię chrzestne, modlitewne, które nie musiało być nawet znane szerszemu ogółowi ${ }^{9}$. Osobisty aspekt modlitw

${ }^{6}$ Nieco szerzej treści maryjne uwzględnili B. N a d o l s k i, Teologiczne treści w „Modlitewniku Gertrudy”, „Studia Theologica Varsaviensia” XXXIII, 1995 s. 49 i A. A n d r ze ju k, Elementy kultury religtjnej w Modlitewniku Gertrudy Mieszkówny, „Ogród” VIII, 2003 nr 1-2, S. $\overline{8} \overline{8}-\bar{y} \overline{0}$.

${ }^{7} \mathrm{~W}$ nawiasach podaję numerację modlitw wedle krytycznej edycji łacińskiej - Modlitwy księżnej Gertrudy... 2002. Zachowuję w zasadzie przyjętą w tym wydaniu ortografię, wprowadzając jednak więcej dużych liter dla imion własnych.

${ }^{8}$ V. N. La z a ri e v, Mozaiki Sofii Kijevskoj, Moskva 1959, il. 22, 24; t e n ż e, Drevnerusskije mozaiki i freski XI-XV w., Moskva 1973, il. 18; G. N. Logvin, Ukrainskoje iskusstvo X-XVIII w., Moskva 1963, s. 23-24, il. 9; R. M a z u rk i ew i c z, Deesis. Idea wstawiennictwa Bogarodzicy $i$ sw. Jana Chrzciciela w kulturze średniowiecznej, Kraków 1994, il. 52. R. M a z urkiewicz powiązał $z$ ideą Deesis tekst Bogurodzicy oraz inne staropolskie utwory i przedstawienia malarskie, tamże, s. 163-218.

${ }^{9}$ A. P o p pe, Gertruda - Olisawa, regina Russorum. Materialy do życiorysu, [w:] Scriptura custos memoriae. Prace historyczne, pod red. D. Zydorek, Poznań 2001, s. 578. Autor 
związanych właśnie z osobą Jaropełka Piotra, przesyconych szczególną żarliwością macierzyńskiej miłości i niepokojów, widoczny tu pewien paralelizm między osobą modlącą się jako matką oraz obiektem jej modłów - synem (filius meus) z jednej strony, a Matką Boga i jej Synem - Chrystusem (filius tuus) z drugiej, były już przedmiotem szczegółowych analiz ${ }^{10}$.

Pozostaje natomiast zwrócenie większej uwagi na problemy ogólniejszej natury. Uderza zwłaszcza niezwykłe bogactwo zastosowanych tytułów i epitetów maryjnych. Przede wszystkim powtarza się dwuczłonowy tytuł, posiadający charakter jakby literackiego oksymoronu - Dei genitrix uirgo semper. Łączy on przyznany Marii przez sobór w Efezie w 431 r. tytuł Boga rodzicy, z tytułem wiecznej Dziewicy (ten ostatni w modlitwach występuje także w formach - uirgo perpetua, uirgo perhennis, uirgo castissima, uirgo uirginum). Podnoszone jest jej chwalebne, cudowne, nienaruszone dziewictwo (laudabilis virginitas, admirabilis virginitas, illibate decus virginitatis). Inne określenia akcentują element wybrania Marii spośród wszystkich kobiet - omniumque feminarum Deo dilectissima oraz jej charakter Bożej, nietkniętej oblubienicy - pulcherrima et intacta sponsa eterni Dei, mater innupta creatoris (znów oksymoron), wyniesionej ponad chóry aniołów super choros angelorum i jako takiej królowej aniołów i całego świata - nobilissima regina angelorum, domina et regina totius orbis.

Wiąze się z tym wspominany i w innych modlitwach motyw wstawiennictwa i orędownictwa. Maria to czynna, wiecznie modląca się w niebie orędowniczka oratrix celorum, nadzieja nędzników - spes miserorum, pociecha bardzo laskawa - benignissima consolatio. Do niej ucieka się Gertruda, najmniej godna ze wszystkich chrześcijan - omnium christicolarum indignissima ${ }^{11}$. Do niej, występującej na innych miejscach jako niepokalana - immaculata (np. 21), zwraca się na zasadzie antytezy - brudna, splamiona, różnymi występkami skalana - sordida, polluta, uariisque uiciis maculata. Ucieka się jako do jedynej swej nadziei - unica spes mea, jedynej słodyczy - unica dulcedo mea, świętego pocieszenia - sancta consolacio mea. Wyznaje, że choć tak niegodna, nieraz już doznała pomocy, co ośmiela ja z nadzieja prosić o dalsze wstawiennictwo. Przedmioty jej próśb sa osobiste, ale i tak ogólne jak pokój i jedność Kościoła. Maria bowiem jest nie tylko sławetna - gloriosa, błogosławiona i przejasna - benedicta et preclara, najszlachetniejsza - nobilissima, najdobrotliwsza - piissima, ale i ,wszechmocna" -

przedstawia poza tym zwyczaj przyjmowania przez kobiety wchodzące do rodu męża nowych imion - Gertruda przyjęła na Rusi imię Elżbieta (Olisawa), jej synowa Kunegunda - Irena.

${ }^{10}$ T. M i c h a ł ow s k a, dz. cyt., s. 83, 88-89.

"Zwrot cum omnium christicolarum indignissimam tantam pietatis dulcedinem dignata es ostendere - ,gdy ze wszystkich chrześcijan najniegodniejszej taką słodycz miłości raczyłaś okazać”, B. Kürbis przetłumaczyła nieproprawnie jako „skoro raczyłaś okazać taką słodycz Twojej miłości, jakiej żaden chrześcijanin nie jest godny", Modlitwy księżnej Gertrudy, 1998 s. 211. To tłumaczenie polskie uznane za "znakomite" (zob. np. A. P o p p e, Gertruda-Olisawa..., dz. cyt., s. 575), przed publikacja, jak widać, niestety nie zweryfikowane, kryje sporo przeinaczeń, błędów i opuszczeń, a ponadto nie oddaje specyfiki formy oryginału (np. celowe, retoryczne powtórzenia uległy zróżnicowaniu słownemu, nie zostały zachowane rymy). Tlumaczka choć podkreślała piękno wybranych modlitw i np. wzorowanie się na greckim hymnie Akatyst (Modlitwy księżnej Gerirudy, dz. cyt., 1998, s. 207; t a ż, Modlitwy księżnej Gertrudy, dz. cyt., 2002, s. 89), nie zgadzała się jednak z uznawaniem modlitewnika za dzieło literackie, uważając go li tyłko za świadectwo religijności epoki. Szeregu walorów formalnych nie dostrzegała i tym samym nie oddała $w$ tłumaczeniu. 
omnipotentissima. Ten epitet przyshugujący w zasadzie tylko Bogu jest tu niewątpliwie użyty dla podniesienia jej najwyższej mocy sprawczej jako pośredniczki i orędowniczki - wiecznej Oranty.

Samodzielne przedstawienie Marii jako Oranty - oratricis celorum, w szczególnie monumentalnej i olśniewającej formie mozaikowej Gertruda miała znów przed oczyma we wnętrzu katedry kijowskiej, gdzie ośmiometrowa jej postać zajmuje miejsce w konsze głównej apsydy (il. 1). Ujęta w antykizującym kontrapoście, unosi się na ozdobnym podnóżku na tle złotego, abstrakcyjnego tła zaświatów. Sylweta Marii jest potężna, krępa, promieniująca siłą. Oranta wznosi ku górze obie ręce o rozłożonych dłoniach. Tuż ponad nimi umieszczono skróty greckiego podpisu Bogarodzicy - Meter Theou. Jej twarz tchnie spokojem, napawającym nadzieją. Odziana jest w błękitną szatę i fioletowo-złotawy płaszcz i maforion, spływające $z$ głowy i spowijające ją malowniczymi fałdami ${ }^{12}$.

W odróżnieniu od noszących charakter osobisty modlitw błagalnych, w których nie tyle była istotna kompozycja całości, co ich żarliwie zagęszczona treść, dwie modlitwy o charakterze wyłącznie pochwalnym odznaczają się zwartym i retorycznie kunsztownym układem $(28,86)^{13}$. Obydwie rozpoczynają się słowami pozdrowienia anielskiego z Ewangelii Łukaszowej (Lk 1, 28). Dalszy ciag modlitwy 28 ułożony jest w rymowane człony (frazy połączone są następującymi rymami: 2 i 3 -letare, portare, 4 i 5 -conditorem, salvatorem, 6 do 9 -suscepisti, concepisti, protulisti, meruisti). Rymy charakteryzowały zarówno łacińskie wiersze (np. leoniny), jak i retoryczna, uroczystą prozę średniowiecza. We frazach 6, 7 i 9 występuje aliteracja - na początku powtarza się trzykrotnie słowo gaude "wesel się", często stosowane w hymnologii maryjnej średniowiecza. Modlitwa jest w całości pochwałą boskiego macierzyństwa Marii, która poczęła w swym łonie „Króla królów”, nosiła tego, który był Stworzycielem wszystkiego i wydała na świat jako jego Zbawiciela.

Podobne teologiczno-retoryczne paradoksy wplecione zostaly również w jedną z dwóch wspomnianych modlitw błagalnych (87) - ten, którego nie jest zdolny objąć świat, pomieszczony został w jej łonie, władca nieba i ziemi był jej poddany jako syn matce przez lat trzydzieści (quem totus non capit orbis tuo gremio collocaretur ... et dominator celi et terre per triginta spatium annorum ut filius matri tibi obedienter subderetur). Sa to wszystko refleksyjne wyrazy zdumienia i zachwytu nad tajemnicą wcielenia Chrystusa oraz relacją zaistniała pomiędzy Bogiem i człowiekiem za pośrednictwem Marii, w dużej mierze idące w ślady za Akatystem, najsławniejszym greckim hymnem narracyjno-lirycznym z VI w., przetłumaczonym ok. 800 r. na łacinę.

7. boskim macierzyństwem Marii wiąże sie jedna 7. nięcin miniatur zwią̧anych z modlitwami Gertrudy, jedyna z nich namalowana na wolnej karcie Psalte-

\footnotetext{
${ }^{12}$ V. N. L a z a r e v, Mozaiki..., dz. cyt., s. 99-102, il. 27-28; t e n ż e, Drevnerusskije mozaiki..., dz. cyt., il. 20-22; G. N. Logvyn, Sofija Kiivska, Kijv 1971, il. 50.

${ }^{13}$ Wyszukana formę literacką niektórych zwłaszcza modlitw silniej podkreśliła jedynie M. H. M a l e w i c z, Rękopis Gertrudy Piastówny, najwcześniejjszy zabytek piśmiennictwa polskiego, [w:] Materialy do historii filozofii średniowiecznej w Polsce, V 1972, s. 55-56, 62. Skoncentrowana na treściach autobiograficznych modlitw, T. M i c h ał o w s k a główną uwagę poświęcała wątkom indywidualnym, a nie ogólnym, zaklasyfikowanym jako konwencjonalne, uznając jednak całość za dzieło o walorach literackich (dz. cyt., s. 54). O stanowisku B. Kürbis por. przyp. 11
} 
rza Egberta (fol. 41 r - il. 2). Maria siedzi na bardzo wysokim, ozdobnym i złotym tronie, $\mathrm{z}$ pofałdowaną tkaniną na zaplecku, na dwóch poduszkach, ze stopami na wysokim podnóżku. Odziana jest w czerwoną szatę, szfirowy płaszcz zarzucony na lewe kolano i zapewne jeszcze jeden ciemny płaszcz oraz maforion spływający z głowy. Dłońmi o niezwykle smukłych palcach obejmuje czule Jezusa. Prawą przytula go do swego łona, lewą okala jego ramię. Jezus to typ młodzieńczego Emmanuela $z$ wysokim czołem, w nimbie krzyżowym, błogosławiacego i trzymającego zwój. Ujęty frontalnie w pozie siedzącej, nie tyle jednak siedzi na kolanach Matki, co unosi się na jej przedpiersiu. Całość gęsto szrafowana złotem, wokół również złote tło oraz prostokąt geometrycznej bordiury ${ }^{14}$. Dwie linie modlitwy (62), wpisane na tej karcie nie odpowiadają wprawdzie treściowo miniaturze, ale ileż do niej odniesień znajdujemy w omawianych modlitwach maryjnych. Oto Dei genitrix ze swym Synem i promieniejąca słonecznym złotem aureoli i szat, majestatyczna domina et regina totius orbis, nobilissima regina angelorum (87). Madonna $z$ frontalnie ujętym Synem, tronująca lub stojaca to typ Nikopoi - Przynoszącej zwycięstwo, razem z typem Oranty należąca do przedstawień symboliczno-dogmatycznych ${ }^{15}$.

Druga maryjna modlitwa pochwalna ( 86 - zob. Aneks I) składa się z dwudziestu czterech fraz, z zastosowaniem retorycznej aliteracji - pierwsza fraza powtarza wstępne słowa pozdrowienia anielskiego i każda następna rozpoczyna się od słowa „Aue". W oryginale, pisanym minuskułą romańska, wszystkie litery „A" wyróżnione zostały większymi rozmiarami (z których niektóre zbliżone są do uncjały, niektóre do kapitały). Szereg fraz jest powiązanych rymami, występującymi tak wewnątrz, jak i na ich końcu. Frazy 1 i 2 to pochwały Marii jako najpiękniejszej, „ponad słońce”, oblubienicy króla nieba i ziemi. Zastosowano tu grę słów sola i super solem ${ }^{16}$. Wprawdzie słońce było symboliczną figurą przede wszystkim Chrystusa, Słońca prawdziwego, Słońca sprawiedliwości, Słońca nieznającego zachodu (Sol verus, Sol iustitiae, Sol occasum nesciens) ${ }^{17}$, zaś Marii odpowiadała figura Gwiazdy i Gwiazdy morza (Stella maris), to jednak zdarzają się w średniowiecznej hymnologii maryjnej, w ślad za starotestamentową Pieśnią nad pieśniami (Pnp 6, 9 - aurora consurgens, pulchra ut luna, electa ut sol) porównania nie tylko gwiezdne, ale także lunarne i solarne (tota ut sol rutilans, ut sol splendi$d a$ ), a nawet pochwały przewyższania słońca (qui splendore praees soli) ${ }^{18}$.

${ }^{14}$ M. S morąg-Ró ży ck a, dz. cyt., s. 165-184, tabl. V, il. 128-135. W jednym szczególe trudno się jednak zgodzić z autorką - dwubarwność szat na kolanach nie jest chyba niekonsekwencją. Słuszniej tłumaczy to złożonością szat B. Kü r b is, Modlitwy księżnej Gertrudy, 2002 dz. cyt., s. 62.

${ }^{15}$ C. N a u e rth, Maria. Marien Frömmigkeit. Ikonographisch, [w:] Teologische Realenzyklopädie, Bd XXII, Berlin - New York 1992, s. 158.

${ }^{16}$ B. Kürbis mylnie podała „pod słońcem”- Modlitwy księżnej Gertrudy... 1998, dz. cyt., s. 206, co zostało również dwukrotnie powtórzone we wstępie do wydania lacińskiego, Modlitwy księżnej Gertrudy, 2002, dz. cyt., s. 89, 92. W thumaczeniu modlitwy 86 ponadto pominięte zostało we frazie 6 określenie de visceribus, we frazie $7 \mathrm{w}$ miejsce kolebki (in cunabulis) wprowadzone zostały ,pieluszki”, z frazy 16 zniknął epitet sancta i opuszczona została cała fraza 21.

${ }^{17}$ J. M i z i ołe k, Secundus Adventus. Chrystus jako prawdziwe stonce w sztuce pierwszego tysiaclecia, „Biuletyn Historii Sztuki” XLIX, 1987, s. 3-48; tenże, Sol verus. Studia nad ikonografia Chrystusa w sztuce pierwszego tysiaclecia, Wrocław 1991.

18 Analecta hymnica medii aevi. Herausgegeben von G. M. Dreves, t. IV, Leipzig $1888 \mathrm{~s}$. 37; The Hundred Best Latin Hymns. Selected by J. S. Phillimore, London 1926, s. 64; W. 
W późniejszej ikonografii przyjmie się szeroko identyfikacja Marii z niewiastą apokaliptyczną „odzianą w słońce” (,,amicta sole”), z wieńcem z gwiazd dwunastu wokół głowy i księżycem pod stopami (Ap 12, 1-2).

Następne frazy, od 3 do 16 , to przypomnienie wszystkich najważniejszych wydarzeń z życia Marii w łączności z życiem Chrystusa. Frazy 3 do 5 mówią o zwiastowaniu i poczęciu, z zastosowaniem rymów salutata (,pozdrowiona"), obumbrata (,ocieniona”). Z kolei frazy od 6 do 11 , spięte jednym rymem kolejnych czasowników: meruisti generare (,zasłużyłaś, aby porodzić”), revinxisti (,,spowiłas'), misisti (,zanurzyłas”), declinasti (,złożyłaś”), presentasti („ofiarowałaś”), genuisti (,porodziłaś") - oddają czynną rolę Marii jako rodzicielki i matki, dwa razy podkreślając nie tylko wydanie na świat Syna Bożego, ale i typowo kobiece, macierzyńskie czynności - spowicie w chusty, zanurzenie w kapieli, złożenie $\mathrm{w}$ żłobie, ofiarowanie w światyni. Frazy od 12 do $16 \mathrm{z}$ dalszymi rymami audisti i trzykrotnie powtórzonym ,uidisti” ukazują jej rolę jako świadka - nauczania, ukrzyżowania, zmartwychwstania i wniebowstapienia Chrystusa. I wreszcie frazy 17 do 21 to znowu długa sekwencja pochwał związanych z różnymi istotami czczącymi i zwracającymi się o pomoc do Marii - angelorum, celorum, sanctorum, iustorum, perditorum, z płynnym, nierymowanym, uogólnionym zakończeniem fraz 22 do 24 .

Modlitwa 86 obfituje w obrazowe elementy, odpowiadające ikonograficznym przedstawieniom narracyjnym, rozbudowywanym stopniowo w pierwszym tysiącleciu istnienia sztuki chrześcijańskiej. Jako ich podstawę wykorzystywano przy tym nie tylko zwięzłe teksty kanoniczne, lecz także obfitujące w barwne szczegóły apokryfy oraz tworzone w nawiązaniu do nich średniowieczne opowieści. Prześledźmy przynajmniej niektóre cykle przedstawieniowe $\mathrm{z}$ epoki, zwłaszcza te, z którymi mogła mieć lub na pewno miała styczność Gertruda. W odczuciach ludzi tamtych stuleci zdecydowaną wyższość posiadała sztuka chrześcijańskiego Wschodu ${ }^{19}$.

Wystrój kościołów i zasoby artystyczne istniejące niegdyś w Polsce zniszczyła, niestety, katastrofa państwa Mieszka oraz późniejsze kataklizmy dziejowe. Z kręgu sztuki późnoottońskiej na terenie cesarstwa dzieł malarstwa ściennego zachowało się co prawda niewiele, dość bogato jest natomiast reprezentowane miniatorstwo oraz rzeźba. Gertruda musiała być z nimi zżyta od czasów młodości. W okresie drugiej ucieczki z Rusi zaistniała dla niej ponadto okazja zobaczenia na terenie Niemiec nowo fundowanych obiektów, przynależnych już do sztuki wczesnoromańskiej.

W ciagu 1075 i 1076 r. wygnańcy przebywali w różnych częściach cesarstwa, m.in. najpewniej także i w Nadrenii ${ }^{20}$. Gertnuda mogła zatem wówcras odwiedzić grób nieżyjącej od 1063 r. matki. Rycheza pragnęła być pochowana

D z i elski, Hymny maryjne dawne $i$ wspólczesne $w$ odnowionej liturgii godzin, „Roczniki Teologiczno-Kanoniczne" XXVI, 1979, zesz. 6, s. 71. Określenia tego typu spotykamy również w staropolskich pieśniach - „Nad gwiazdę, nad słońce najaśniejsza”, a nawet „Jaśniejsza tysiąc nad słońce”, zob. Jaśniejsza tysiąc nad stonce. Pieśni i modlitwy maryjne z tzw. Kancjonalu kórnickiego, oprac. R. Mazurkiewicz, Kraków 2000, s. 23, 30.

19 A. Ró ży cka-B ryzek, Przeciw stereotypom myślenia o sztuce bizantyńskiej, „Znak"nr 466, 1994, s. 52.

${ }^{20}$ T. M i ch a ło w s k a, dz. cyt., s. 178-179. 
w rozbudowanym przez siebie kościele w Brauweiler, fundacji rodziców, pogrzebano ją jednak w Kolonii, w kościele NMarii Panny na Kapitolu (grób jej otoczony był nawet $w$ wiekach średnich kultem, później przeniesiony do katedry, znajduje się w niej do dziś, posiadając formę klasycystyczna).

Kościół na Kapitolu przebudowała opatka Ida (jedna z sześciu sióstr Rychezy, opatek w archidiecezji kolońskiej), choć nie doczekała jego konsekracji w 1065 r., zmarła bowiem jeszcze wcześniej, w 1060 r. Pozostałością rzeźbiarska wyposażenia z czasów Idy, przetrwałą do dnia dzisiejszego, są dwuskrzydłowe wrota wysokości pięciu metrów, zamykające pierwotnie wejście południowe transeptu. Jest to dzieło skromne $\mathrm{w}$ zastosowanym materiale, wykonane bowiem w drewnie (il. 3). Zawiera jednak aż dwadzieścia sześć kwater różnej wielkości, obrazujących serię mariologiczno-chrystologicznych scen, od Zwiastowania po Wniebowstapienie i Zesłanie Ducha Świętego, w jakby ludowej, prostej formie, ze stłoczonymi na niewielkich powierzchniach, ale obdarzonymi niezwykłą siłą ekspresji postaciami (całość była niegdyś polichromowana) ${ }^{21}$.

Zwiastowanie jako początek Wcielenia było tematem bardzo często przedstawianym i Gertruda miała niewątpliwie przed oczyma również i inne, różnorodne wersje sceny, w której Maria została „przez anioła pozdrowiona” (,ab angelo salutata"). Być może znała miniaturę w Sacramentarium z kościoła Św. Gereona w Kolonii, powstałego na przełomie X i XI w., do której bardzo zbliżona jest analogiczna miniatura z Ewangeliarza z Meschede (klasztoru w Westfalii) z ok. $1020 \mathrm{r}^{22} \mathrm{Mi}$ niatury z Ewangeliarza zasługują na szczególną uwagę $\mathrm{z}$ tej racji, że fundatorką dzieła była opatka klasztoru, Hidta. Charakteryzuje je szkicowość i malarskość wykonania, ogromna ekspresja barw i kształtów. W obydwóch scenach Zwiastowania na pierwszym planie stoi Maria zwrócona nietypowo, bo profilem, a naprzeciw niej aniol, ze stale powtarzanym „gestem mówienia" (średniowiecze znało i utrzymywało przynajmniej częściowo rozbudowany język gestów starożytności). W Ewangeliarzu opatki Hidty anioł jakby wlatuje $z$ innej przestrzeni w przestrzeń obrazu koniec jego jednego skrzydła i stopy znajdują się bowiem przed obramieniem miniatury (i1. 4). Maria z Sacramentarium wysuwa do przodu obie dłonie zapewne gestem pytania, postać $\mathrm{z}$ Ewangeliarza jedną dłoń ma podniesioną w górę - jest to już zapewne gest akceptacji - fiat. W tle pietrzą się budowle miasta, ale wokól postaci w Sacramentarium, a w Ewangeliarzu w tle Marii rozsnuwa się falista kulisa, charakterystyczna dla obu serii miniatur. Kulisy te określa się też jako „zasłonę” lub „górę" czy „pieczarę”, bo nie wiadomo, czy są wypukłe, czy wklęsłe. Najpewniej wydzielaja one jak gdyby odrębną przestrzeń sakralną cudownego wydarzenia. W Ewangeliarzu opatki Hidty ma ona kolor jasnofioletowy, co odpowiadałoby tu słowom o ogarnięciu-ocienieniu (,obumbrata”) Marii przez Ducha Świętego.

W mozaikach bizantyńskich na Marię spływa na ogół snop światła, z widoczną czasem na nim Gołębica. Maria siedzi, zaskoczona przez Gabriela, to znów powstaje na jego widok $\mathrm{z}$ tronu ${ }^{23}$. W katedrze kijowskiej miała również taką

${ }^{21}$ H. J a n t z e n, Ottonische Kunst, München 1947, s. 33, 41-43, 130-131, il. 118-1 19.

${ }^{22} \mathrm{P}$. B I o c h, H. S chn itzle r, Die Ottonische Kölner Malerschule, Bd. I, Düsseldorf 1967, s. 38, 47, il. 85, 125, Bd. II, Düsseldorf 1970, s. 93-94; H. J a n t z e n, dz. cyt., s. 90-91.

${ }^{23}$ O. D e m u s, Byzantine Mosaic Decoration, London 1947, il. 4 (Daphni); tenże, The Mosaics of Norman Sicily, London 1949, il. 11 (Palermo, Capella Palatina), 49 (Palermo, Martorana). 
scenę przed swymi oczyma Gertruda, z postaciami ponaddwumetrowej wysokości (il. 1). Kroczący Gabriel w białej szacie lekko mieniącej się jasnymi tonami zieleni i fioletu, z czerwoną laseczką posłańca i rozwianymi końcami wstążek we włosach, oznaczającymi działanie, znajduje się na podłuczu północnej arkady. Po przeciwległej stronie południowej widnieje ujęta prawie frontalnie Maria. Tu artysta nie uwidocznił przestrachu ani zaskoczenia - dał jej wyraz spokoju i zadumy ogromnych oczu. Greckie napisy przytaczaja słowa pozdrowienia Gabriela i poddania się woli Bożej przez Marię („Oto ja służebnica Pańska, niech mi się stanie według słowa twego" - Łk 1, 28). W rękach, podobnie jak na innych bizantyńskich Zwiastowaniach, Maria trzyma wrzeciono i czerwoną nić, mocną linią przecinająca jej szafirową szatę ${ }^{24}$. Artyści greccy nawiązywali do Protoewangelii Jakuba i Ewangelii Pseudo-Mateusza, opowiadających o dwóch epizodach Zwiastowania - głosie anioła słyszanym najpierw przez Marię przy studni i dalszej jego części, jaka rozegrała się już we wnętrzu domu. Maria zajęta była wówczas przędzeniem nici na zasłonę do Świątyni jerozolimskiej, ubarwionej purpurą którą przekazał jej uprzednio arcykapłan (ProtEwJk X, 1-2, XI, 1-3, XII, 2; PsMt IX, $1-2)^{25}$. Cały cykl związanych $z$ tym scen powstanie w XII w. w kościele Św. Marka w Wenecji ${ }^{26}$.

Na Zachodzie Hrotsvita (ok. 935 - po 975), pierwsza pisarka narodowości niemieckiej, zakonnica w Gandersheim (gdzie później opatką była jedna $z$ ciotek Gertrudy), korzystając $z$ apokryfów ułożyła metrycznym daktylem (dactilicis modulis) opowieść pt. Historia nativitatis laudabilisque conversationis intactae Dei Genitricis quam scriptam repperi sub nomine Sancti Jacobi fratris Domini, w której jest mowa także i o tym, jak Maria przed zwiastowaniem „błogosławionymi palcami przędła purpurowe nici" (Purpureos digitis filos operans benedictis) ${ }^{27}$. Dopiero pięćset lat później w Rozmyślaniu przemyskim powiedziano w języku staropolskim, ze Maria „robięcy swą robotę, sukała złoto na jedwab i pawłoki a pawłokę tkała" ${ }^{28}$.

Apokryfy w szczególnie dramatyczny sposób i to w wielu zróżnicowanych wersjach przedstawiały jednak przede wszystkim temat Bożego Narodzenia. Wymaga on też szczególowej analizy, jako że jedna z miniatur w Kodeksie Gertrudy, rozbudowane szesnastopostaciowe przedstawienie jest mu właśnie poświęcona (fol. 9v - il. 5). Kanoniczne źródło - Ewangelia św. Łukasza jest ogromnie lakoniczna, mówi tylko o wypełnieniu dni do porodu Marii i o tym, że gdy porodziła, owinęła Syna płótnami i złożyła w żłobie, gdyż nie było dla przybyszów miejsca $\mathrm{w}$ gospodzie - Et peperit filium suum primogenitum et pannis eum involvit et reclinavit eum in praesepio, quia non erat eis locus in diversorio (Lk 2, 6-7). Najwcześniej̧sze przedstawienia Bożego Narodzenia w sztuce, datujące się z IV i V w., są w ślad za tym bardzo proste. Ukazują Marię, lub Marię i Józefa siedzących

${ }^{24}$ V. N. L a z a r e v, Mozaiki..., s. 123-124, il. 60-63; tenże, Drevnerusskije mozaiki..., il. 52-55; G. L o g v i n, Ukrainskoe iskusstvo..., s. 18; tenże, Sofia Kiivska..., il. 38, 40.

${ }^{25} \mathrm{~W}$ nawiasie podaję odniesienia do apokryfów wedlug wydania - Apokryfy Nowego Testamentu. Ewangelie apokryficzne, red. M. Starowieyski, t. I, cz. 1-2, Kraków 2003.

${ }^{26}$ O. D e m u s, The Mosaics of San Marcoin Venice, I, vol. 2, Chicago 1984, tabl. 41.

${ }^{27}$ H r o t s u i th a, Opera. Recensuit et emendavit P. de Winterfeld, Berolini 1900, s. 4-29.

${ }^{28}$ Rozmyślanie przemyskie, wyd. F. Keller i W. Twardzik, Freiburg im Breisgau 1998 t. I, s. 92. 
przy żłobku z nowo narodzonym, spowitym Dzieciątkiem, $z$ widocznymi nad nim dwoma zwierzętami - osłem i wołem ${ }^{29}$. Ich obecność już w trakcie podróży do Betlejem thumaczyły apokryfy i opowieści średniowieczne praktycystycznie osiołek niósł brzemienną Marię, a wół przeznaczony na sprzedaż miał zapewnić utrzymanie. Jednocześnie jednak zwierzęta te miały potwierdzać wypełnienie się proroctw Izajasza (Iz 1, 3) oraz Habakuka (Ha 3, 2). Takie proste i lapidarne ujęcie Bożego Narodzenia utrzymywało się nadal poprzez wieki i ogląała je zapewne Gertruda na Drzwiach Kolońskich - Maria i Józef siedza tu symetrycznie, $\mathrm{z}$ głowami wspartymi na dłoniach $\mathrm{w}$ gestach zatroskania, po bokach wysokiego żłobka $\mathrm{z}$ kolumienka, a sponad spowitego Dzieciątka wyglądają łby zwierząt.

Od Vw. przyjął się jednak także wizerunek Marii leżącej lub półleżącej na podróżnym posłaniu (macie, sienniku), a w sztuce zachodniej niekiedy na łożu. Posłanie przedstawiane bywało z góry, usytuowane ukośnie lub niemal pionowo. Natomiast siedzący nadal Józef został bardziej wyeliminowany, przesunięty na ubocze. Układ ich postaci w stosunku do Dzieciątka bywa różny. I tak np. na miniaturze z Sacramentarium od Św. Gereona Matka i Dzieciątko zwrócone są do siebie twarzami, Józef z pochyloną głową i opuszczonymi na kolana dłońmi siedzi naprzeciw Marii, z kolei w Ewangeliarzu opatki Hidty Maria odwrócona jest plecami od Dzieciątka, Józef zatroskany przesunięty w prawą stronę, co w sumie potęguje wrażenie opuszczenia i bezradności (il. 6). Maria spoczywa tu na pomarańczowym posłaniu, z rękami spowitymi długimi rękawami o koronkowych bramowaniach $^{30}$.

W Bożym Narodzeniu z Kodeksu Gertrudy również nie ma relacji między Matka a Synem. Maria (o wyolbrzymionej jak i inne postaci głowie) odziana w niebieską suknię widoczną spod czerwonego maforionu, półleży na typowym białym posłaniu ozdobionym kolorowymi pasami, o zaokraglonym jak gdzie indziej wezglowiu, ale przeciwległym końcu odmiennie zakończonym prosto, z frędzlą. Ponad nią stoi żłobek z Dzieciątkiem, spowitym ciasno błękitnym płótnem. Józef siedzi natomiast na pierwszym planie, w lewym dolnym narożu, ze wspartą siwą głową, spoglądając w górę przez ramię.

Często występującą i zastanawiającą pozę odwrócenia Józefa próbowano interpretować jako wyraz negacji ojcostwa, przejęty z ikonografii antycznej (ze sceny narodzin Aleksandra Wielkiego), trudno jednak, by analogiczny odwrócony układ odnosić do Marii ${ }^{31}$. Zatroskanie Józefa thumaczą natomiast dostatecznie wszystkie szeroko przedstawione w apokryfach watki opowiadające o jego rozpaczy, datującej się od odkrycia brzemienności Marii, o poddawaniu ich obojga upokarzającym próbom, o rozterkach w czasie podróży, o ciagłym zmaganiu się z sytuacją i tajemnica, jaka stała się jego udziałem, wreszcie o zwyczajnych trudach, szukaniu pomieszczenia dla rodzącej i zabiegach o znalezienie położnej. Jó-

${ }^{29}$ Np. na oprawie z kości słoniowej z V w., zob. T. M i c h a $\nmid$ o w s k a, dz. cyt., il. 23.

${ }^{30}$ P. B l o ch, H. S ch n it zl e r, dz. cyt., Bd. I, s. 38,47, il. 87, 127; Bd. II, s. 95.

${ }^{31}$ M. S mor ąg - R ó ż y c k a, dz. cyt., s. 135, il. 98 (narodziny Aleksandra), tabl. III, il. 93-97, 99 (inne sceny Bożego Narodzenia). W żadnym natomiast wypadku nie można się zgodzić ze sformułowaniem, że Józef ,adoruje" scenę Bożego Narodzenia (P. S t r óż y k, Wyobrażenia wtadców na "ruskich" miniaturach z Kodeksu księżnej Gertrudy, [w:] Historia bliższa $i$ dalsza. Polityka - Spoleczeństwo - Wojskowość, red. S. Kow al, G. K u c harski, M. W a 1 c z a k a, Poznań-Kalisz 2001, s. 50; Modlitwy księżnej Gertrudy, 2002, s. 60). 
zef bywał czasem ukazywany bez aureoli, wielki rozwój jego kultu jako opiekuna Św. Rodziny datuje się bowiem dopiero z czasów nowożytnych. Apokryfy rozwijają tym niemniej szeroko jego starania i zabiegi, podobnie jak i jego syna, nazywanego Jakubem lub Symeonem, którego pieczy pozostawia Józef Marię idąc szukać położnych. Poleca mu umyć Marii nogi i nakarmić, a Symeon okazuje jej we wszystkim ogromną troskliwość (KsNarZb 6).

W modlitwie 86 wykorzystany został Łukaszowy passus o zawinięciu Nowonarodzonego w płótna i złożeniu w żłobku przez samą Marię. We frazie 7 jest nawet mowa o kolebce, dopiero we frazie 9 o żłobku, co nie jest czasowo logicznym uszeregowaniem, chyba że in cunabulis należy rozumieć w sensie - ,jak do kolebki", bo tej tuż po narodzeniu przecież brakowało. W opowieści Hrotsvity jest w duchu antynomii mowa o Marii spowijającej i składającej do ciasnego żłobka wiecznego króla (Collocat angusto praesepi membra tenella / Christi, panniculis regem volvendo perennem). Ta osobista czynność Matki znajdowała również niekiedy swoją wizualizację. Marię pochyloną nad żłobkiem i dłońmi obejmującą czule główkę lub ramionka spowitego Jezusa przedstawia mozaika w Hosios Loukas na Focydzie z XI w. oraz późniejsze mozaiki z kościołów Palermo ${ }^{32}$. Dzieciątko jest zawsze przedstawiane jako mocno skrępowane wraz z głową płótnami (chustami), czasem dodatkowo przewiązane sznurkami (dlatego też w thumaczeniu nie stosuję określenia ,pieluszki”, budzącego inne skojarzenia). Na miniaturze gertrudiańskiej nie brak oczywiście osiołka i wołu. Jest nawet widoczna zgięta noga osiołka, wyraz przyklęku, cudownego adorowania Stworzyciela przez bezrozumne bydlęta (PsMt 14, 1).

Fraza 9 modlitwy 86 mówi o tym, że Maria Syna Bożego „w kapieli zanurzyła". Przedstawienie Marii z Dzieciątkiem koło basenu z wodą odkryto jak dotąd tylko na koptyjskiej tkaninie z VI w., ale wiadomo także o realnym kamiennym basenie, pokazywanym pielgrzymom $\mathrm{w}$ Betlejem $\mathrm{w}$ VII w. ${ }^{33} \mathrm{~W}$ ikonografii wschodnio-chrześcijańskiej przyjąl się temat kapieli Nowonarodzonego być może w ślad za przedstawieniami antycznymi narodzin Dionizosa i Aleksandra, dokonywanymi przez asystujące przy położnicy kobiety. Dzieciątko kapią z reguły dwie położne i widnieją one również na pierwszym planie miniatury $z$ Kodeksu Gertrudy. Średniowieczną metoda „kontynuacyjna” ukazano epizod wcześniejszy w stosunku do przedstawienia Jezusa w żłobku. Przy złotym basenie o kształcie fontanny-kielicha siedzi kobieta w czerwieni i prawą ręką trzyma na kolanach nagie Dziecię, lewą sprawdzając temperaturę wody, obok kobieta w niebieskiej sukni leje $z$ góry wodę $z$ dzbana, zapewne rozgrzanego $i$ dlatego podtrzymywanego przez czerwoną chustę. $\mathrm{Na}$ wspomnianej mozaice $\mathrm{z}$ Hosios Loukas widać obok basenu wytryskajace ze skały źródłn, ale przecież do kanielii trzeba było donieść i ciepłą wodę.

Antyczna rodzajowa scena kapieli noworodka w sztuce chrześcijańskiej nabrała znaczenia prefigury chrztu. Będzie później występować stale także w scenach narodzin Marii oraz świętych (obecna jest np. na romańskich Drzwiach Gnieźnieńskich poświęconych św. Wojciechowi). W ikonografii Bożego Narodzenia dawała sposobność dyskretnego upamiętnienia postaci dwóch akuszerek,

${ }^{32}$ M. S m or a g - R ó ż y c k a, dz. cyt., il. 95 (Hosios Loukas); O. D e m u s, The Mosaics of Norman Sicily..., il. 17, 55 (Palermo, Capella Palatina i Martorana).

${ }^{33}$ M. S m or ą g-R ó ż y c k a, dz. cyt., s. 138. 
o których apokryfy opowiadały szeroko, w sposób nieraz drastyczny i bez osłonek, bliski współczesnej nam literaturze naturalistycznej i brutalistycznej (EwDzArab 3; EwJ 6, 1; ProtEwJk 18-20; PsMt 13; KsNarZb 4-18; EwDzOrm VIII, 5-11, IX, 2-6). Ich cel był jednak zgoła odmienny, było nim bowiem uwierzytelnienie cudownych okoliczności i nadnaturalności Wcielenia Chrystusa, spełnienia się proroctwa Izajasza o dziewiczym macierzyństwie (Iz 7, 14-15) i dobitnego potwierdzenia dziewictwa Marii. Opowieści apokryficzne przeciwstawiają na ogół dwie położne - jedna, która uwierzyła w cud dziewiczego macierzyństwa (noszącą imię Zahel lub Zelemi), oraz druga (o imieniu Salome), która powątpiewając, pokarana najpierw paraliżem ręki, następnie została uzdrowiona cudownie przez Dzieciątko. Już jednak św. Hieronim pisał z dezaprobatą o „bredzeniu apokryfów” („deliramenta apocryphorum"), napotykały one stale opory, a Sobór Trydencki usunął je ostatecznie z horyzontu wyobraźni wiernych.

We wszystkich tekstach apokryficznych i opartych na nich następnych opowieściach jest wprawdzie mowa o utrudzeniu podróżą brzemiennej Marii, jednocześnie jednak i o tym, że porodziła bez bólu i upływu krwi, że również jej Syn nie był skalany żadną nieczystością. Piersi Dziewicy natomiast wypełniły się mlekiem i Jezus jak każde człowiecze dziecko zaczął je ssać (ProtEwJk 19, 1-3; PsMt 13, 3; KsNarZb 15). W modlitwie 87 ze zbioru Gertrudy znajdujemy apostrofę do Marii, podkreślającą jeszcze jeden paradoks - że oto „chleb anielski” żywił się jej mlekiem (panis angelorum tuo lacte pasceretur).

W ślad za opowieściami apokryficznymi w przedstawieniach Bożego Narodzenia pojawia się jedna lub dwie akuszerki. Kobieta, podobnie zamyślona jak Józef (nad tajemnicą, której stali się uczestnikami i świadkami), siedzi u stóp Marii, jak na syryjskiej plakiecie $z$ VII-VIII w. ${ }^{34}$ lub też stoi u jej wezgłowia ${ }^{35}$. Ważny dla kręgu Gertrudy obiekt stanowi oprawa księgi ze złotej repusowanej blachy, z plakietą z kości słoniowej pośrodku, fundacji jednej z jej ciotek - Theophanu, opatki w Essen. W dolnym pasie złotej bordiury widoczna jest sama Theophanu w towarzystwie dwóch świętych, w pokłonie przed tronującą Madonną. Plakieta środkowa ukazuje trzy spiętrzone sceny - Boże Narodzenie, Ukrzyżowanie i Wniebowstapienie. Na samym dole Madonna spoczywa na łożu, przykryta pofałdowaną kołdra, z gestem przyzwolenia podniesionych dłoni. Nad nią pochyla się kobieta, ujmujacc kraniec kołdry - musi to więc być Zahel, której badanie miało służyć dobru Marii jako zwykłej kobiety, a wykazało jej cudowne dziewictwo ${ }^{36}$. Znane są też przedstawienia nie dowierzającej Salome z wyciagniętą ku Marii rę$\mathrm{ka}$ jak na trudnych do datowania freskach $\mathrm{z}$ Castelseprio koło Mediolanu ${ }^{37}$.

W największej ilości przedstawień, jak na miniaturze Gertrudiańskiej, położne ujęte zostały w scenie $\mathrm{z}$ kapiela - zawsze jedna $\mathrm{z}$ nich, zgodnie $\mathrm{z}$ opowieściami apokryficznymi, jest starsza, doświadczona (wierząca Zahel), druga to młoda pomocnica, przedstawiana bardziej strojnie (watpiąca Salome). Na miniaturze Zahel

${ }^{34}$ M. S mo rąg - R ó ż y c k a, dz. cyt., il. 99.

${ }^{35}$ P. B loch, H. S ch n i tzle r, dz. cyt., Bd. II, il. 351.

${ }^{36} \mathrm{H}$. J a n $\mathrm{z}$ e n, dz. cyt., s. 140 . 149, il. 146.

${ }^{37}$ A. R ó ż y c k a - B r y z e k, Malowidla ścienne w kościele Santa Maria w Castelseprio, „Rocznik Historii Sztuki” III, 1962 il. 11. Zob. też Z. K l i ś, Temat Bożego Narodzenia w polskiej sztuce średniowiecznej, Kraków 1994, s. 42-53. 
ma na głowie czepiec mężatki, Salome piękną fryzurę z wstążkami i kolczyki ${ }^{38}$. Jej młodość usprawiedliwia niejako okazane początkowo niedowiarstwo. Sama kąpiel w świetle tekstów zupełnie się jednak nie tłumaczy, skoro Dzieciątko, odmiennie od innych noworodków, było zupełnie czyste, ,jakby skapane w rosie Boga Najwyższego". Do tego od razu stało, siedziało (wyobrażenia kapieli oddaja takie właśnie jego pozy), nie płakało, uśmiechało się słodko (KsNarZb 15).

Apokryfy rozmaicie przedstawiały scenerię Bożego Narodzenia. Większość umiejscawia je w czarnej grocie, do której nie dochodziło światło słoneczne, a która rozświetliła się niezwykle jasnym światłem od chwili wejścia do niej Marii (PsMt 13), bądź w samym momencie narodzin Chrystusa (KsNarZb 15). Wedle tej ostatniej wersji, Zahel widziala Marię trwająca w zachwyceniu i nadnaturalną świałłość, która powoli koncentrując się przybrała postać dziecka. Inne apokryfy z kolei opowiadają o wyszukanej przez Józefa zagrodzie pasterskiej (EwBarn 3), względnie „stajni stojącej na osobności”, która zdaniem Józefa była odpowiednim schronieniem - położonym ,z daleka od gwaru ludzi tak, że nie będą oni szkodzili rodzącej niewieście" (KsNarZb 5). Niekiedy stajnia była jednak identyfikowana z jaskinią (KsNarZb 5-6; EwDzOrm VIII,6)). Wedle jeszcze innej wersji Maria z Dzieciątkiem przeniosła się po trzech dniach z groty do stajni, gdzie pozostawała znów przez trzy dni (PsMt 14,1).

Stąd też różnorodność przedstawień wizualnych. W Sacramentarium z kościoła Św. Gereona i w Ewangeliarzu opatki Hidty widać ścianę stajni z arkadkami, z których wychylają się zwierzęta, a wyżej w tle piętrzą się budowle Betlejem (il. 6). W ikonografii wschodniej i pozostającej pod jej wpływami ukazywana jest natomiast ziejąca czernia grota w skalistym pejzażu. Scena Bożego Narodzenia niejako wylewa się z jej środka na zewnątrz. Takie przedstawienie, podobnie jak sceny umieszczane w łukach arkad, w edikulach lub przed nieproporcjonalnie małymi budowlami należy według wczesnośredniowiecznych konwencji artystycznych pojmować jako ukazanie scen rozgrywających się we wnętrzach lub innych przestrzeniach zamkniętych.

Miniatura Bożonarodzeniowa z Kodeksu Gertrudy przedstawia jednak ponadto niezwykłe rozwiązanie symboliczno-przestrzenne. Grota z otaczającym skalistym pejzażem jest bowiem wkomponowana w niebywale ozdobnie ujętą strukturę architektoniczną świątyni. Prostokąt sceny obramia dziesięć pasów różnej szerokości, wypełnionych wzorami geometrycznymi i florystycznymi. Górę

${ }^{38} \mathrm{Na}$ bardzo zatartej głowie Gertrudy wyobrażonej na miniaturze ze św.Piotrem (fol. 5v) można dojrzeć kolczyk w formie białego kółka z trzema wisiorkami. Ponieważ kolczyk taki ma rówriléz posiać z kieiichem na miniaturze z ükrzyżowanıem (tol. 10r), dopatrywano się tu pierwotnie postaci Gertrudy (jest to personifikacja Ecclesii). To samo odniesione zostało do położnej w niebieskiej szacie. Wszystkie te domniemania sq nieuzasadnione, jak słusznie podkreśla M. S m o r ą g - R ó ż y c k a, dz. cyt., s. 25, 130, 143, 153-154. Ostatnio doszło jeszcze zupełnie nieumotywowane lączenie twarzy Gertrudy $z$ cherubinem na miniaturze $z$ tronujacym Chrystusem (fol. 10v) - A. Andrzejuk we Wstepie do: Gertruda M ieszkówna, Modlitewnik. Wybór, "Ogród" VIII, 2003 nr 1-2, s. 37-38. Nieuzasadnione jest ponadto identyfikowanie jej z księżną w Izborniku Swiatosława (Modlitwy księżnej Gertrudy, 2002, s. 68) - przedstawiona tu została bez wątpliwości obok męża Światosława księżna Oda ze swymi synami. Nie wiadomo natomiast, czy wedle pierwotnego zamysłu Gertrudę nie wyobrażała stojaca wraz z mężem Izjasławem postać kobieca przed św. Piotrem (Modlitewnik księżnej Gertrudy, 2002, s. 54-55 oraz podpisy do ilustracji okładkowej i czwartej nieliczbowanej). 
zdobią równie ozdobnie potraktowane dwa trójkątne szczyty po bokach środkowego półkola, nad którymi piętrzą się z kolei trzy wieże zwieńczone kopułami i złotymi krzyżami (środkowy uległ obcięciu, gdyż tzw. folia Gertrudiana przed połączeniem z Psałterzem Egberta musiały być nieco wyższe).

W środkowej arkadzie widać błękitne wycinki empireum niebiańskiego, a z niego spływający w dół snop światła z czerwoną gwiazda, adorowaną po bokach przez dwa anioły. Snop światła przenika pod poprzecznymi pasami bordiur i uwidacznia się nad grota, adorowany tu przez trzech aniołów, wyłaniających się spoza skał. Czwarty anioł zwraca się do stojącego poniżej starego pasterza z laską i obwieszcza mu nowinę ${ }^{39}$.

W swym poemacie Hrotsvita mówi o świetle i zastępie aniołów adorujących „Dziecko zesłane nam z gwiazdy" (puerum nobis e sidere missum). W modlitwie 87 znajdujemy apostrofę do Marii jako nadziei i pociechy rodzaju ludzkiego, której poród wiązał się $z$ obwieszczeniem pokoju przez anioły $(O$ spes et solatium humani generis, in cuius partu angeli pacem omnibus predicabant). Na miniaturze przedstawiono zatem boską światłość towarzyszącą Bożemu Narodżeniu, Adorację anielską oraz Zwiastowanie pasterzom (pasterzowi). Mamy tu jeszcze ponadto w obrębie skalnego pejzażu postaci trzech Magów spieszących z lewej strony w kierunku Marii i Dzieciątka, a więc zapowiedź mającej nastappić w sekwencji wydarzeń Bożonarodzeniowych sceny Hołdu. W osobach starca, męża w sile wieku i młodzieńca są oni przedstawicielami trzech etapów drogi ludzkiego życia. Najmłodszy wskazuje w górę ręką na gwiazdę, która ich przywiodła.

Bardzo zbliżone symboliczne świątynie przedstawiają miniatury w Izborniku Światosława, dziele powstałym na Rusi ok. 1073 r., obramiają one jednakże nie sceny o charakterze narracyjnym, ale grupy świętych ${ }^{40}$. W połączeniu sceny narracyjnej ze strukturą świątyni przypominają natomiast Gertrudiańskie Boże Narodzenie miniatury bizantyńskie z pierwszej połowy XII w., wyobrażające Wniebowstapienie $^{41}$. W odniesieniu do Bożego Narodzenia znajdujemy w apokryfach sformulowania wyraźnie inspirujące takie właśnie rozwiązanie. Oto Józef z pramatką Ewą zdążając do wejścia do groty zobaczyli „otwierającą się kopułę nieba”, silne światło spływające $z$ góry, „kolumnę płomiennej pary” ponad grota i jednocześnie usłyszeli śpiewy aniołów (EwDzOrm 11). Podobnie powiedziano o samej jaskini, że „stała się w tym czasie podobna do niebieskiego kościoła, ponieważ usta niebiańskie i ziemskie czciły i wielbiły narodzenie Pana Jezusa" (EwDzArab, 4). Architektonicznie "oprawne" sceny Bożego Narodzenia oraz Wniebowstapienia mogły posiadać jakieś wcześniejsze pierwowzory, skoro oba dotyczyły szczególnych momentów łączności empireum niebiańskiego i ziemi, uzmysłowionych właśnie wspólną strukturą świątyni.

Jednocześnie oddziaływać tu mogły realne wiadomości o betlejemskiej Grocie, nad którą powstała bazylika w czasach Konstantyna Wielkiego. Wprawdzie

${ }^{39}$ Nie sq̨ to anioly bezskrzydłe (P. S tró ży k, dz. cyt., s. 50; Modlitwy księżnej Gertrudy, 2002, s. 59). Można dojrzeć trzy łuki skrzydeł i dwa ich końce.

${ }^{40}$ Zob. O. I. P o d o b e d o v a, Jeszczo odin aspekt izuczenija miniatjur Izbornika Sviatostava, [w:] Drevnerusskoje iskusstvo. Rukopisnaja kniga, sbornik tretij, Moskva 1983, s. 80-88; M. S m or ą g-Róż y c k a, dz. cyt., s. 215, il. 198-199.

${ }^{41}$ O. D e mu s, Byzantine Mosaic Decoration..., il. 62 b; M. S morąg-Ró ży c k a, dcyt., s. 215, il. 201 
budowla ta nie posiadała kopul, ale w VII w. zyskała absydowe zamknięcie zachodnie w formie trójliścia, co powtórzył m.in. kościół NMarii Panny na Kapitolu w Kolonii, rozbudowany, jak wspomniano, przez opatkę Idę, ciotkę Gertrudy ${ }^{42}$. Był on miejscem dorocznych, szczególnie uroczystych mszy, odprawianych w Boże Narodzenie przez arcybiskupów kolońskich. Być może w grudniu 1075 r. uczestniczyła w tej liturgii także i Gertruda z Izjasławem. Dwustronność skojarzeń: kosmos-świątynia i światynia-kosmos będzie trwać w myśli i sztuce chrześcijańskiej poprzez wieki. „Radujcie się..., którzy dostrzegacie jakby drugie niebo na ziemi w poświęconym dzisiaj kościele", mówił patriarcha Focjusz w $864 \mathrm{r}^{43}$

Boże Narodzenie w Kodeksie Gertrudy jest połączone ze sceną Adoracji przez anioły, Zwiastowania pasterzom i zapowiedzią Hołdu trzech króli, tak jak to charakteryzuje wiele wschodnich przedstawień. Wyodrębnioną scenę Hołdu, z tronującą Madonną z Dzieciątkiem i pomniejszonymi postaciami Magów, znajdujemy na wielu miniaturach zachodnich, m.in. w Ewangeliarzu Hidty, ukazaną na tle purpurowej „kulisy”,44. Scenom Zwiastowania pasterzom oraz Hołdu poświęcone są odrębne kwatery Drzwi Kolońskich. Na dalszych kwaterach Maria jest tu ponadto obecna w scenie Ucieczki do Egiptu - siedząca frontalnie na osioł$\mathrm{ku}, \mathrm{z}$ Jezuskiem śpiącym w łuku jej ramion. Ostatnim epizodem maryjnym na lewych podwojach drzwi jest Ofiarowanie w świątyni - Maria podaje Dzieciątko starcowi Symeonowi. Tę scenę uwzględnia również cykl z Ewangeliarza opatki Hidty, gdzie Dzieciątko podaje jednak Józef, zaś Maria trzyma dwa ofiarne gołąb$\mathrm{ki}^{45}$. Odpowiadają one frazie $10 \mathrm{z}$ modlitwy 86 , po której fraza 11 podkreśla raz jeszcze rolę Marii jako cielesnej rodzicielki Chrystusa (ofiarowanie było jednocześnie dniem zwyczajowego oczyszczenia po połogu, od którego Maria się nie uchyliła).

Następne frazy modlitwy, poświęcone roli Marii - świadka nauczania (fraza 12) i życia Jezusa (fraza 14-16), nawiązują znów zarówno do źródeł ewangelicznych, jak i apokryficznych. Ewangelie implikowały obecność Marii w czasie działalności nauczycielskiej Chrystusa, opowieści apokryficzne przekazywały wyznania samej Marii (ZapB 2, 1-5, 15) i inspirowały powstanie rozbudowanych dialogów między Matką i Synem, wyjaśniającym Jej wszystkie prawdy wiary. Ewangelicznie poświadczona jest natomiast przede wszystkim obecność Marii pod krzyżem (J 19, 25-27), której poświęcona jest fraza 14, wizualnie przedstawiana w niezliczonych scenach Ukrzyżowania, obecna również w postaci osobnej miniatury w Kodeksie Gertrudy, na karcie sąsiadującej z miniaturą Bożego Narodzenia (fol. 10r) ${ }^{46}$.

Fraza 15 modlitwy mówi o oglądaniu przez Marię Chrystusa zmartwychwstającego. Ewangelie poświadczają ulkazywanie się Chrystusa Marii Magdalenie („Noli me tangere"), apostołom i uczniom przez czterdzieści dni po zmartwychwstaniu (Mt 28, 9-10, 16-20; Mk 16, 9-18, Łk 24, 13-49; J 20, 11-31, 21, 1-21). Apokryficzna Ewangelia Barnaby opowiadała o pojawieniu się Chrystusa w oto-

\footnotetext{
${ }^{42}$ Por. przyp. 32.

${ }^{43}$ F o c ju s z, Homilia X, tłum. M. Dzielska, Wstęp, A. Ró ż y c k a - B r yz e k, „Znak”

${ }_{44}^{4}$ P. B l o c h, H. S c h n i t z l e r, dz. cyt., Bd. I, s. 47, il. 129.

${ }^{45}$ Tamże, s. 47 , il. 131

${ }^{46}$ M. S m o r a g - R ó ż y c k a, dz. cyt., tabl. IV.
} nr 466, 1994, s. 61. 
czeniu czterech archaniołów także i jego Matce (EwBarn, CCIX-CCXX). Wzrastający stale kult Matki Bożej obfitował w domniemania na ten temat. Sw. Ambroży już w IV w. pisał: „Zobaczyła więc Maria zmartwychwstanie Pana, pierwsza zobaczyła i uwierzyła" (Vidit ergo Maria resurrectionem Domini, et prima vidit et credidit). Georgios - metropolita Nikomedii z IX w. mówił w homilii o wspaniałej wizji oglądanej przez Marię przy grobie Syna, która od niego w ogóle nie odeszła. Roman Melodos, twórca Akatystu, jest także autorem kontakio$n u$, w którym na żale Matki pod krzyżem Chrystus odpowiada obietnica, że ona pierwsza go ujrzy zmartwychwstającego. Źródeł pisanych o tym przekonaniu na Zachodzie i Wschodzie zatem nie brakowało. W ikonografii natomiast temat nie był długi czas przedstawiany, poza „ogrodowa”" wersją ukazania się nie tylko Marii Magdalenie, ale i dwum niewiastom - Matce Bożej wraz z Marią Magdalena. Dopiero jednak w późniejszym średniowieczu scena wejdzie częściej do ikonografii w formie inspirowanej przez Pseudo-Bonawenturę ${ }^{47}$.

Fraza 16 mówi o oglądaniu Chrystusa wstępującego w niebo. W licznych scenach Wniebowstapienia nie zawsze ukazywano Marię. Nie ma jej np. na miniaturze z Sacramentarium od Św. Gereona, jest natomiast na Drzwiach Kolonskich, gdzie scenę przedstawiono dwupoziomowo, na dwóch kwaterach - w górnej Chrystusa w nimbie unoszą anioły, w dolnej wybija się w grupie apostołów postać Marii z wzniesionymi w górę rękoma (ukazana profilem, jak na wspomnianych miniaturach bizantyńskich). Jest to jedyne jej wyobrażenie na prawym, chrystologicznym skrzydle wrót. Postacie Matki i Syna tworzą wspólny pion dla obu stref. Współbrzmia z takim ujęciem końcowe słowa frazy16, w których podkreślone zostało raz jeszcze macierzyństwo Marii - odejście Chrystusa do nieba wraz z ciałem, które od niej otrzymał.

Problemem stale powracającym i kontrowersyjnym jest autorstwo modlitw. Część badaczy uznała Gertrudę za ich autorkę, część wysuwała wątpliwości, dopuszczajac, że autorem mógł być jej kapelan. Obecnie wiadomo, że niektóre modlitwy występują i w innych zbiorach, że były zatem kopiowane i należały do szerszego obiegu. Przyszłe badania może odkryja, że kunsztowne modlitwy 28 i 86 znajdują się i w innych libelli precum, nie ulega jednak wạtpliwości, że ich słowami modliła się Gertruda Mieszkówna, wielka księżna kijowska, w czasach rządów piątego pokolenia chrześcijańskich władców polskich, w czasach życia okrytego mgła tajemnicy św. Stanisława biskupa, z których nie przetrwał żaden inny polsko-łaciński indywidualny modlitewny głos.

Najpiękniejsza z modlitw maryjnych z Modlitewnika Gertrudy - modlitwa 86 rozbrzmiewała na polskiej ziemi w wiekach późniejszych i doczekała się przekładu na język polski - znajdujemy ją bowiem w modlitewniku z końca XV w.

${ }^{47}$ J. D. B reckenridge, "Et prima vidit". The Iconography of the Apperance of Christ to his Mother, "The Art Bulletin” XXXIX, 1957, s. 9-32, il. 1 (Matka Boża i Maria Magdalena u stóp Chrystusa - miniatura z syryjskiego Ewangeliarza Rabuli z końca VI w.); T. D o b rz en i e k i, Legenda średniowieczna wpiśmiennictwi i sztuce. Chrystofania Marii, [w:] Sredniowiecze. Studia o kulturze, t. II, Wrocław 1965, s. 7-131. 
zwanym dziś Modlitewnikiem Nawojki (zob. Aneks II) ${ }^{48}$. O czterysta lat późniejszy rękopis został wydany w $1823 \mathrm{r}^{49}$ Wydał go Jan Motty, Francuz o włoskich korzeniach, syn oficera armii napoleońskiej, osiadły w Wielkopolsce, który dał początek rodzinie wielce zasłużonej dla kultury tego regionu ${ }^{50}$. Jako nauczyciel języka i literatury francuskiej natknął się u jednego ze swych uczniów na małego formatu książeczkę do nabożeństwa. Doceniając niezwykłość dziełka, jako należącego do „najdawniejszych pomników mowy polskiej w piśmie używanej”, zatroszczył się o jego publikację w facsimilowej formie według ówczesnych możliwości.

Ma ono wymiary ok. 9 na $6 \mathrm{~cm}$. Do drukowanego w transliteracji tekstu dołączone zostały litograficzne podobizny 48 pierwszych stron tekstu pisanego gotykiem, z rysowanymi piórkiem ozdobnikami na marginesach. Okładka oddaje przednią i tylną oprawę oryginału, $\mathrm{z}$ tarczami typu renesansowego, $\mathrm{z}$ monogramem JK oraz Orłem Zygmunta I (oplecionego literą S). Całość okrywa tekturowy futeralik, imitujący srebrną skrzyneczkę zamykaną na klamry, z barokowymi wiciami roślinnymi oraz inskrypcją z $1634 \mathrm{r}^{51}$ Rękopis jeszcze przed połową XIX wieku zaginąl, a poszukiwania doprowadzily tylko do odnalezienia skrzyneczki w zamku Fischbach na Śląsku (dziś Karpniki w rejonie Jeleniej Góry). Pierwodruk, ale już bez opraw zewnętrznych, powtórzył po zaginięciu oryginału syn Jana - Stanisław Motty, poznański prawnik w 1875 r. (wydania modlitewnika w Krakowie 1849 r. i Wilnie w 1856 r. nie posiadają wartości). Do końca XIX stulecia modlitewnik wzbudzał ogromne zainteresowanie i polemiki historyków literatury i języka staropolskiego, dotyczące czasu powstania, proweniencji, autorstwa i właścicieli rękopisu.

Modlitewnik obfituje w modlitwy maryjne, przez pierwszych wydawców nie rozdzielone i nie numerowane. Zaraz jednak po części wstępnej wyróżnia się modlitwa z powtarzanymi dwudziestokrotnie ,Zdrowa bąđź”, która doczekała się analizy i rozpisania na frazy przez Franciszka Krčka w jego studium poświęconym językowi modlitw ${ }^{52}$. Autor ten ustalił pierwowzory do dwóch trzecich z ogólnej ich liczby, do modlitwy tej pierwowzoru całości nie znalazł. Połączył jednak typ

${ }^{48}$ Za zwrócenie mi uwagi na podobieństwa Modlitw Gertrudy i Modlitw Nawojki dziękuję dr Wioletcie Zawitkowskiej, zajmującej się postacią Nawojki z Koniecpolskich Bnińskiej, autorce artykułu Modlitewnik Nawojki (Kilka uwag o cennym zabytku piśmiennictwa polskiego i jego autorce. Na marginesie badań nad dziejami rodziny Koniecpolskich w wiekach średnich), „Kresy Południowo-Wschodnie. Rocznik Regionalnego Ośrodka Kultury, Edukacji i Nauki w Przemyślu" I, 2003, z. 1, s. 19-29. Dziękuję również prof. dr. hab. Romanowi Mazurkiewiczowi, który wskazał mi na swoją edycję Teksty o Matce Bożej. Polskie średniowiecze. Wstęp, wyoúr i upracowanie R. Mí a z u rk i e w i c z, Niepokalanów 2000̂, s. 49-5í, gdzie uwzgiędniona została modlitwa Nawojki i wskazana zbieżność z modlitwą Gertrudy 86 na podstawie jej tłumaczenia polskiego B. Kürbis. W Aneksie Il wykorzystuję zastosowaną tu transkrypcję.

${ }^{49}$ Ksiazzeczka do nabożeństwa, na której się modlita Ś. Jadwiga, Poznań 1823.

${ }^{50}$ Zob. Z. G rot, Motty Jan Chrzciciel, [w:] Polski stownik biograficzny XXII, Wrocław 1977, s. 153-154 oraz inni członkowie rodziny, tamże, s. 154-157.

${ }^{51}$ Inskrypcja głosi: „Libellus precarius quo utebatur S. Hedvigis ducissa, ab eminentissimo cardinale Bernardo Maciejowski ill[ustrissi]mae sorori suae Annae Wapowska castellanae pramisliensi et per eius nepotem Stanislaum Wapowski Societatis Jesu huic templo munere datus Anno 1634 II Octobris".

${ }^{52}$ F. K r če k, Modlitewnik Nawojki, ,Rozprawy Akademii Umiejętności Wydział Filologiczny", seria II, t. 8 (23), Kraków 1894, s. 194-200. 
modlitwy z łacińskimi „,salutationes” i niemieckimi „Mariengrüsse”. Przypuszczał, że modlitwa weszła do języka polskiego z łaciny lub niemieckiego, dodatkowo poprzez „alembik” czeski.

Modlitwa powtarza zasadniczą sekwencję wezwań z modlitwy 86 Gertrudy, ale wykazuje pewne wzbogacenia i przetworzenia. Salutacje „Zdrowa bądź” obrosły dodatkowymi apostrofami - ,gospodze” (frazy 2-4, 7), „pani” (frazy 5-6, 12), „krolewno" (frazy 8-9, 14), ,dziewko" (fraza 10), z towarzyszącymi im epitetami „chwalebna”, „wyśmienita” (doskonała), ,znamie[n]ita”. Początkowe porównanie „Bożej porodzicielki” do słońca uzupełnione jest o lunarne - „nad słońce i nad miesiąc cudniejsza" ${ }^{\text {,53 }}$. Frazy 7 i 8 łączą macierzyńskie czynności Marii, w drugiej $\mathrm{z}$ nich jest mowa o powijaniu w pieluchy i pokładaniu w jasłkach, w pierwszej o „dojeniu” i „kębłaniu”, ${ }^{\text {"54 }}$. Rażące dziś nasze uszy „dojenie” to odpowiednik pojenia, karmienia piersią (łać. lactare), którego nie ma w modlitwie 86, ale, jak wspominaliśmy, występuje w modlitwie Gertrudy 87, w ślad za wieloma wzmiankami apokryficznymi. Czasownik zapisany w oryginale jako „kamblala” różnie był przez językoznawców rozumiany, albo jako „kapała”, albo „kębłała”, czyli karmiła, piastowała. Zmianę w stosunku do łacińskiego oryginału i ewentualnej wcześniejszej polskiej wersji na blisko brzmiący czasownik tłumaczyć może stopniowy zanik sceny kapieli w ikonografii Bożego Narodzenia w późniejszym średniowieczu.

Rzecz znamienna również z punktu widzenia ikonograficznego, że po frazie 10, mówiącej o oglądaniu syna rozpiętego na krzyżu; pojawia się fraza 11 o oglądaniu go „umarłego i za nas pogrzebionego”, odpowiadajaca z kolei rozwojowi tematu zdjęcia z krzyża, opłakiwania i złożenia do grobu. Utrzymana została natomiast wersja o oglądaniu Chrystusa „wstając z martwych” (fraza 12). Inne frazy dość wiernie idą za modlitwą gertrudiańską, łącząc jednak niektóre lub dodając, jak np. frazę 19, poświęconą, „najświętszej nad wszystkimi niewiastami”.

Krček zauważył, iż pierwowzór musiał się odznaczać rymowaniami, które występują i w wersji polskiej. Dodajmy, z przetworzeniami. Wprowadzony został jednolity rym - „kębłała”, „powijała”, „pokładała”, „ofierowała”, „oglądała”, „obejrzała”, „widziała”. Nie rymuja się , anjołem zawitana” i ,ogarniona duchem świętym". Pojawiają się natomiast rymy „w kościele", „w ciele” oraz „rozbitego", „umarłego", „pogrzebionego". Tłumacz lub kolejni tłumacze wprowadzali swoje innowacje.

Także w tzw. Modlitewniku Konstancji, zachowanym w rękopisie skopiowanym być może z wcześniejszego w 1527 r., występuje modlitwa o sekwencji dwunastu ,Wesel się panno Maryja”, gdzie pobrzmiewają nawiązania do modlitwy $86^{55}$. Skomasowano razem wszystkie macierzyńskie czynności w jednej frazie: „Wesel się panno Maryja, któraś piastowała, karmiła, kapała, powijała i w jasłki pokładała jako człowieka Jezu Krysta Bożego Syna i piersiami swymi świętymi

${ }^{53}$ Krček znalazł łaciński odpowiednik - „Ave sole purior, luna plena pulchrior”, tamże s. 200 i podobnie wskazal na określenia ab angelo salutata i per spiritum sanctum obumbrata, występujące w litanii św. Bonawentury, tamże, s. 197-198.

${ }_{54}$ Tamże, s. 198. Zob. Stownik staropolski, t. II, Wrocław 1956, s. 108 (doić); t. III, Wrocław 1960-1962, s. 264 (kębłać).

${ }^{55}$ W. Wisłocki, Modlitewnik siostry Konstancji, „Sprawozdania Komisji Językowej Akademii Umiejętności" III, 1884 s. 173-174. 
jego karmiła, ale jako Boga chwaliła i jemuż się modliła". Tu stają nam przed oczyma XV-wieczne sceny Bożego Narodzenia $\mathrm{z}$ adorującą nowo narodzone nagie Dzieciątko klęczącą Madonną, co wzięło swój początek z objawień św. Brygidy. W Modlitewniku Konstancji jest już też mowa o pozdrowieniu Matki przez „swego syna milego po jego zmartwychwstaniu”, w wersji wprowadzonej przez św. Bonawenturę, co znalazło odzwierciedlenie w przedstawieniach Marii w jej komnacie z pojawiającym się przed nią Zmartwychwstałym ${ }^{56}$. Tu też ciąg dalszy odnosi się do Wniebowzięcia i Koronacji Matki Boskiej. Te rozbudowane i przyobleczone w nowe kształty stylowe cykle posiadamy w postaci wielu gotyckich malowanych i rzeźbionych tryptyków i poliptyków, by wspomnieć krakowskie ołtarze - Dominikański, Augustiański oraz arcydzieło Wita Stwosza w kościele Mariackim ${ }^{57}$.

Powstaje pytanie, jakimi drogami modlitwa 86 mogła przejść do modlitewnika z końca XV w. W dziejach Kodeksu Gertrudy znanych jest osiem kolejnych kobiecych właścicielek. Psałterz Egberta z X w. przywiozła do Polski Rycheza i zapewne zabrała $z$ powrotem do Kolonii, a następnie przekazała córce. Z Gertrudą wędrował on między Kolonią i Kijowem, m.in. trzykrotnie zapewne znajdując się za jej życia w Krakowie. W trudnych do określenia latach dodano do Psalterza kilka rękopiśmiennych dodatków. Najpewniej w okresie między 1078 a 1087 r., a może i wcześniej, dopisane i dołączone zostały do niego modlitwy księżnej. Do Krakowa przywiozła Kodeks ponownie wnuczka Gertrudy Zbysława, wydana za Bolesława Krzywoustego i pozostawał tu lat ponad trzydzieści, między $1103 \mathrm{r}$. a 1139 r., gdy córka Krzywoustego Gertruda z drugiej jego żony Salomei z hrabiów Bergu, zabrała go ze sobą do klasztoru w Zwiefalten, gdzie została mniszka. Poprzez osobę bratowej Salomei Gizeli z rodu Andechs przeszedł on jednak znowu w świeckie ręce i trzecia $z$ kolei Gertruda $z$ tegoż rodu, jako królowa węgierska zabrała go ze soba na Węgry, by z kolei przekazać córce, św. Elżbiecie księżnej Turyngii. Ta ostatnia ofiarowała Kodeks kapitule katedry w Cividale del Friuli w północnych Włoszech, gdzie znajduje się od 1229 r. (obecnie w Museo Archeologico Nazionale).

Czy zatem łacińskie kopie sporządzono w Krakowie już w XI lub XII w., czy zaistniały jeszcze inne późniejsze okazje? Sugestię odpowiedzi dostarcza napis na srebrnej skrzyneczce. Pierwsza karta rękopisu Modlitewnika Nawojki nie istniała w chwili jego publikacji i inskrypcja z XVII w. stała się jedynym przekazem o jego proweniencji. Idąc od końca wstecz mówi on o przekazaniu w 1634 r. dzielka jezuitom przez Stanisława Wapowskiego, który posiadał je po swej babce Annie kasztelanowej przemyskiej, ta zaś otrzymała od swego brata kardynała Bernarda

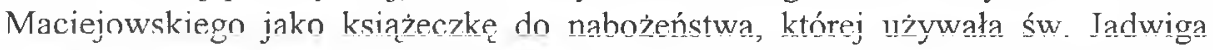
księżna - quo utebatur S. Hedvigis ducissa. Występująca tu jednoznaczna identyfikacja ze św. Jadwigą Ślaska poddana została jednak w watpliwość przez XIXwiecznych badaczy zabytku. Zupelną dowolnością wydało się wszystkim złączenie w XVII w. rękopisu o cechach XV stulecia z Jadwigą żyjącą w pierwszej połowie XIII w. Jan Motty w tytule zachował wprawdzie jej osobę, ale we wstępie

${ }^{56}$ Por. przyp. 47.

${ }^{57}$ Przegląd ikonografii maryjno-chrystologicznej XV w. w związku z tekstami misteriówkazań wraz z odnośnymi opracowaniami zob. K. T a r g o s z, Korzenie $i$ ksztatty teatru do $1500 \mathrm{r}$. w perspektywie Krakowa, Kraków 1995, s. 210-241. 
wyliczył inne Jadwigi, jakie mogłyby wchodzić w grę - z wykluczeniem królowej, były to córki Władysława Jagiełły i Kazimierza Jagiellończyka. Stanisław Motty podał w tytule Jadwigę „,księżniczkę polską" (skrót S. starano się wytlumaczyć jako Serenissima). Już jednak wcześniej, za Wacławem Aleksandrem Maciejowskim, który zwrócił uwagę na występujące w modlitwach czterokrotnie imię Nawojka, przyjęto nazwę Modlitewnika Nawojki ${ }^{58}$.

A jednak św. Jadwiga Śląska (ok. 1178-1243) pochodziła z rodu hrabiów Andechs, była starszą siostrą Gertrudy królowej węgierskiej, a ciotką św. Elżbiety Turyngskiej, mogła zatem posiadać kopię jednej lub większej ilości modlitw z Kodeksu Gertrudy. Patriarchą Akwilei, który nakłonił św.Elżbietę do darowania Kodeksu kapitule w Cividale, był jej wuj, a brat Jadwigi, Bertold. Za Henryka Brodatego wydana została w wieku dwunastu lat, język polski sobie zapewne przyswoiła. Mogła modlić się zarówno po łacinie (przetrwał kodeks należących do niej Godzinek liturgicznych), po niemiecku jak i może po polsku. Jej synową była królewna czeska Anna i ta mogła z kolei używać języka czeskiego. Córka Jadwigi Gertruda, opatka cysterek w Trzebnicy, odziedziczyła zapewne po matce jej spuściznę i niewątpliwie utrzymywała pamięć o niej. Już wówczas zaczęto przekładać teksty łacińskie na narodowe i w II polowie XIII w. na pewno polskie teksty będzie posiadać księżna krakowska św. Kinga. Rękopis Modlitewnika Nawojki nigdy w rękach św. Jadwigi Śląskiej się nie znajdował, ale nie znany jej modlitewnik mógł stanowić zaczątek najstarszej jego części, później tłumaczonej, przerabianej i uzupełnianej, z zachowaniem tradycji o dawnej, kanonizowanej użytkowniczce.

Modlitwy Gertrudy, Nawojki i Konstancji łączy występowanie kobiecego ego gramatycznego $\mathrm{i}$ to $\mathrm{z}$ kilkakrotnym przydawaniem imienia wlasnego. Zwrot „ego Gertruda", którym już tak mało odpowiedzialnie szermuje się w tylu opracowaniach - jakoby powtarzanym „często”, „wielokrotnie”, „raz po raz” i posiadającym charakter zwrotu „dumnego", w rzeczywistości w oryginale nie występuje ani razu. Modlitewnik nie jest dyplomatariuszem dumnej władczyni. To, co pierwszy wydawca odczytywał dwukrotnie jako „ego Gertruda”, w krytycznej edycji uznane zostało za błędne, na rzecz lekcji ego ergo..., ,ja zatem..." (49). Imię Gertrudy widnieje na kartach Kodeksu zaledwie trzykrotnie, zawsze z bardzo kornymi dodatkowymi określeniami - służebnicy i to służebnicy nieszczęsnej i niegodnej - „pro me famula tua Gertruda”, w modlitwie do św. Heleny (18) oraz dwóch modlitwach zwróconych do Chrystusa - „ut me miseram famulam tuam Gertrudam” (93), „mihi indigne famule tue Gertrude” (95). Podobny zwrot występował najpewniej również w jeszcze jednej modlitwie (61), w której wyskrobane zostało później imię Gertrudy, co z oburzeniem zaznaczył na marginesie nowożytny glosator.

Analogiczne zwroty odnajdujemy w modlitewnikach z XV w. i początków następnego. W Modlitewniku Nawojki czterokrotnie występuje imię pełne, raz monogram N. (,mnie Nawojce”, ,ja N.", ,na mię Nawojkę”, „mnie Nawojkę", ,ja Nawojka") $)^{59}$. Jest włączone w prośby do Marii o wstawiennictwo u „swego miłego" Syna i skrócenie mąk w imię jego własnych oraz w prośby do samego Chrystusa, aby miłosiernym okiem wejrzał na nią podobnie jak na Marię Magdalenę, uczynił ,sługą swa”" i wlał w nią Ducha Świętego. Wedle wszelkiego prawdopo-

\footnotetext{
${ }^{58}$ W. A. M a c i e jow s k i, Piśmiennictwo polskie, t. I, Warszawa 1851, s. 363-363.

${ }^{59}$ Ksiazeczka do nabożeństwa... 1823 i 1875, s. 70, 74, 83, 92, 111-112.
} 
dobieństwa nie jest to „bliżej nieznana Nawojka”, ale „magnifica domina” Nawojka czyli Natalia z Koniecpolskich Mosińska-Bnińska (ok. 1463-1531), córka Mikołaja podkomorzego przemyskiego, żona Macieja wojewody poznańskiego, jedna z najmożniejszych kobiet ówczesnych czasów, w życiu osobistym bardzo jednak nieszczęśliwa i doświadczona ${ }^{60}$. W Modlitewniku Konstancji odnajdujemy w zwrotach do Chrystusa „służebnicę twoją Konstancję” i „niedostojną służebnicę twoją Konstancję", wbrew przyjętej nazwie Modlitewnika siostry Konstancji, najpewniej również osobę świecką . Kwestii autorstwa modlitw podnoszonej przez wielu autorów nie sposób rozstrzygnać. Dalsze badania porównawcze ujawnią może jeszcze inne pierwowzory i zbieżności oraz drogi wędrówek kodeksów i modlitw, podobnych do dziejów tej jednej modlitwy maryjnej, łacińskiej i polskiej, dwóch ogniw jednego łańcucha, rozdzielonych przestrzenią czterech stuleci.

\section{Aneks I}

\section{(Modlitwa 86 z Modlitewnika Gertrudy)}

1. Aue Maria gratia plena, Dominus tecum, que es sola pulcherrima super solem.

2. Aue cuius speciem rex celi et terre concupiuit.

3. Aue ab angelo salutata.

4. Aue obumbrata a Spiritu sancto.

5. Aue pregnans Deum.

6. Aue que Filium Dei ex tuis uisceribus meruisti generare.

7. Aue que Filium Dei in cunabulis reuinx[is]ti.

8. Aue que Filium Dei in balneum misisti.

9. Aue que Filium Dei in presepium declinasti.

10. Aue que Filium Dei in templum presentasti.

11. Aue que Filium Dei genuisti secundum carnem.

12. Aue que Filium Dei audisti predicantem nostram salutem.

13. Aue gloriosa et nimis gloriosa.

14. Aue que Filium Dei uidisti in cruce pro nostra redemptione suspensum.

15. Aue que Filium Dei uidisti resurgentem a mortuis per gloriam Patris.

16. Aue que Filium Dei uidisti ad celos ascendentem cum illa carne quam ex te sancta et immaculata uirgine suscepit.

17. Aue domina angelorum.

18. Aue regina celorum.

19. Aue laus omnium sanctorum.

20. Aue exultacio iustorum.

21. Aue recuperatio perditorum.

22. Aue spes nostra.

23. Aue salus nostra.

24. Aue gloriosa mater Domini, Sancta Maria angelorum laude dignissima et a cunctis ueneranda. Amen.

\section{${ }^{60}$ Zob. przyp. 48.}

${ }^{61}$ W.W i s $\nmid$ o c k i, dz. cyt., s. 127, 168. Wydawca uznał właścicielkę modlitewnika za zakonnicę, czemu zdają się przeczyć uwagi o modlitwach przeznaczonych na porę wieczorną i ranna, bez rygorów zakonnego trybu życia (tamże, s. 168). 
(1. Bądź pozdrowiona Maryjo, łaski pełna, Pan z Tobą która jedyna jesteś najpiękniejsza, ponad słonce.

2. Bądź pozdrowiona, której urodę król nieba i ziemi sobie upodobał.

3. Bądź pozdrowiona, przez anioła nawiedzona.

4. Bądź pozdrowiona, ocieniona przez Ducha Świętego.

5. Bądź pozdrowiona, brzemienna Bogiem.

6. Bądź pozdrowiona, która zasłużyłaś sobie, aby Syna Bożego z Twego wnętrza porodzić.

7. Bądź pozdrowiona, która Syna Bożego do kolebki spowiłaś.

8. Bądź pozdrowiona, która Syna Bożego w kapieli zanurzyłaś.

9. Bądź pozdrowiona, która Syna Bożego w żłobku układałaś.

10. Bądź pozdrowiona, która Syna Bożego w światyni ofiarowałaś.

11. Bądź pozdrowiona, która Syna Bożego porodziłaś cieleśnie.

12. Bądź pozdrowiona, która Syna Bożego słuchałaś nauczającego o zbawieniu naszym.

13. Bądź pozdrowiona, chwalebna, jakże bardzo chwalebna.

14. Bądź pozdrowiona, która Syna Bożego widziałaś na krzyżu dla naszego odkupienia zawieszonego.

15. Bạdź pozdrowiona, która Syna Bożego widziałaś powstającego z martwych na chwałę Ojca.

16. Bądź pozdrowiona, która Syna Bożego widziałaś do nieba wstępującego w tym ciele, które z ciebie święta i niepokalana Dziewico otrzymał.

17. Bądź pozdrowiona pani aniołów.

18. Bądź pozdrowiona królowo niebiosów.

19. Bądź pozdrowiona chwało wszystkich świętych.

20. Bądź pozdrowiona radości sprawiedliwych.

21. Bądz pozdrowiona ratunku zgubionych.

22. Bądź pozdrowiona nadziejo nasza.

23. Bądź pozdrowiona zbawienie nasze.

24. Bądź pozdrowiona chwalebna Matko Pana, Święta Maryjo, najgodniejsza chwały aniołów i od wszystkich na cześć zasługująca. Amen.)

tłum. K. T

W powyższym thumaczeniu starałam się oddać jak najwierniej oryginał, powtarzając te same słowa, skoro ich powtarzanie, a nie urozmaicanie słownictwa jest zabiegiem retorycznym, zachowując następstwo słów oraz stosując rymy, tam gdzie one występują. Dla zgodności rymu zamieniłam w niektórych wypadkach czas przeszły dokonany na niedokonany. 


\section{Aneks II \\ (Modlitwa z Modlitewnika Nawojki)}

Zdrowa bądź, Maryja, miłości pełna, Boża Porodzicielko, jaześ nad słońce i nad miesiąc cudniejsza.

Zdrowa bądź, Gospodze chwalebna i barzo wysmienita; jeś znamie[n]ita, jeż oblicza kro] nieba i ziemie pożąal jest.

Zdrowa bądź, Gospodze, anjołem zawitana.

Zdrowa bądź, Gospodze, ogarniona Duchem Świẹtym.

Zdrowa badź, Pani, noszaca Boga

Zdrowa bądź, Pani, iżeś z twego świętego żywota zasłużyła jeś Syna Bożego porodzić.

Zdrowa bądź, Gospodze iżeś Syna Bożego dojiła i jegożeś kębłała.

Zdrowa bądź, Krolewno, ty Syna Bożego pieluchami powijałaa; tyś ji w jasłkach pokładała.

Zdrowa bądź, Krolewno, tyś Syna Bożego w kościele ofierowała, ktoregoś w ciele ogladała i obeźrzała i słyszałaś przepowiedając zbawienie nasze.

Zdrowa bądź, Dziewko chwalebna, ktorażeś Syna Bożego widziała na krzyżu rozbitego za nasze odkupienie.

Zdrowa bądź, ktoraś Syna Bożego widziała umarłego i za nas pogrzebionego.

Zdrowa bądź, Pani, ktoregoś żeś widziała wstając z martwych.

Zdrowa bądź, jak jeś widziała Syna Bożego wstępując na niebiosa do Boga Ojca z ciałem onym, jeż z niepokalonej dziewice przyją́ raczył.

Zdrowa bądź, Krolewno niebieska, anielska, archanjelska i wszech niebios.

Zdrowa bądź uweselenie wszech świetych.

Zdrowa bądź, chwało ludzka.

Zdrowa bądź, oprawienie zgubionych.

Zdrowa badź, nadziejo nasza i zbawienie nasze.

Zdrowa bądź, naświętsza nade wszemi niewiastami.

Zdrowa bądź, Dziewice chwalebna i wszej chwaly dostojna, mimo wszytki cześniejsza. 


\section{Sola Pulcherrima Super Solem - "More Beautiful than the Sun and Month" (Marian Prayer from Gertrude's and Nawojka's Prayer-Books) Summary}

A new critical edition of a collection of nearly one hundred Latin prayers connected with Gertrude of Poland (ca 1025-1 108), Polish princess, wife of Izaslav of Kiev, has revived an interest in this exceptional example of literature and religiousness of the eleventh century. The multiplicity of issues connected with the prayer book requires further consideration. An example might be the iconographic concord of prayers both with the accompanying miniatures and the works of art, which Gertrude encountered in the west as well as in the east - from Rhineland, where she was educated to Ruthenia, where she stayed longest. The paper examines the issue in relation to the Marian subject matter. A problem that has not as yet been touched upon is the history of the prayers in the centuries that followed, as a singular example from the $15^{\text {th }}$ century regarding one such prayer reveals.

The prayers are mostly theocentric and Christocentric in character, but in many of them the intercessive role of St. Mary is evoked. In Ruthenia Gertrude was exposed to representations of the Deesis type, characteristic of eastern Christianity. From the prince's box in St. Sophia's Cathedral in Kiev she saw them in a form of three tondi, situated on the arch encasing the central apse, while in the apse itself was a monumental depiction of St. Mary-Oranta, eternal and omnipotent advocate in heaven, referred to in prayers as "oratrix celorum".

Of the four prayers directed exclusively to Mary two are laudatory and supplicatory and the other two just laudatory. The latter are characterized by a sophisticated literary form, division into phrases, employment of internal and external rhymes and a number of rhetorical figures (alliteration, oxymorons). A solar epithet appears here among others ("sola pulcherrima super solem"). A lot of Marian epithets, such as the Mother of God, Our Lady and the Queen of the whole world ("Dei genitrix", "domina et regina totius orbis") find their equivalent in one of the five miniatures.

In prayer no. 86 the praise refers not only to the significance of St. Mary as the Mother of God, but to her purely feminine and maternal functions and her role of a participant and witness to the life and passion of Christ. They find their equivalents in Marian and Christological artistic series of the time. One of them is a series of scenes on the wooden door of the church Sankta Maria im Kapitol in Cologne, made ca 1050. The church was rebuilt by abbotess Ida, one of Gertrude's aunts, who also funded the door. In this church Gertrude's mother, Richeza, was buried. Gertrude could see the door during her stay in Rhineland in the years 1075-1076. A number of depictions are included in miniatures in the manuscripts from the Ottonian epoch, e.g. a Scripture-Book of abbotess Hitda of Meschede from ca 1020, with an Annunciation scene. Gertrude knew a different presentation of this scene from monumental mosaics in Kiev. The maternity of St. Mary was presented in many different types of the Nativity. An exceptionally extended depiction in the eastern spirit, including a reference to apocryphal texts, is shown in one of the Codex' miniatures.

Prayer no. 86 in its Polish, slightly transformed version appeared after several centuries in the so-called Nawojka's Prayer Book, which most probably belonged to Natalia Bninska, nee Koniecpolska (ca 1463-1531) in a manuscript from the end of the $15^{\text {th }}$ century. The manuscript was lost and today is known from a copy made in the first half of the $19^{\text {th }}$ century, including a copy of the old silver cover - a box from the $17^{\text {th }}$ century. According to the inscription on the box it was supposed to be St. Jadwiga, Duchess of Silesia's (ca 1178-1243) collection of prayers; a tradition which was immediately questioned. It seems, however, to possess a grain of truth. Gertrude's Codex, having changed hands many a time, was presented to the chapter of the Cividale del Friuli Cathedral in 1229, where it has been kept since. It was presented by St. Elizabeth, Princess of Thuringia at the instigation of her uncle Berthold, patriarch of Aquilea. Elizabeth was Jadwiga of Silesia's niece and Berthold was her brother. If the prayer had not been copied at the time when Gertrude's Codex was in Cracow (and it was there as many as three times), then it could have been Jadwiga's relatives who had it copied. At an unspecified time it was translated from Latin into Polish for Jadwiga or for the next generations of women in Poland and the translation was transformed until the $15^{\text {th }}$ century version was reached. 


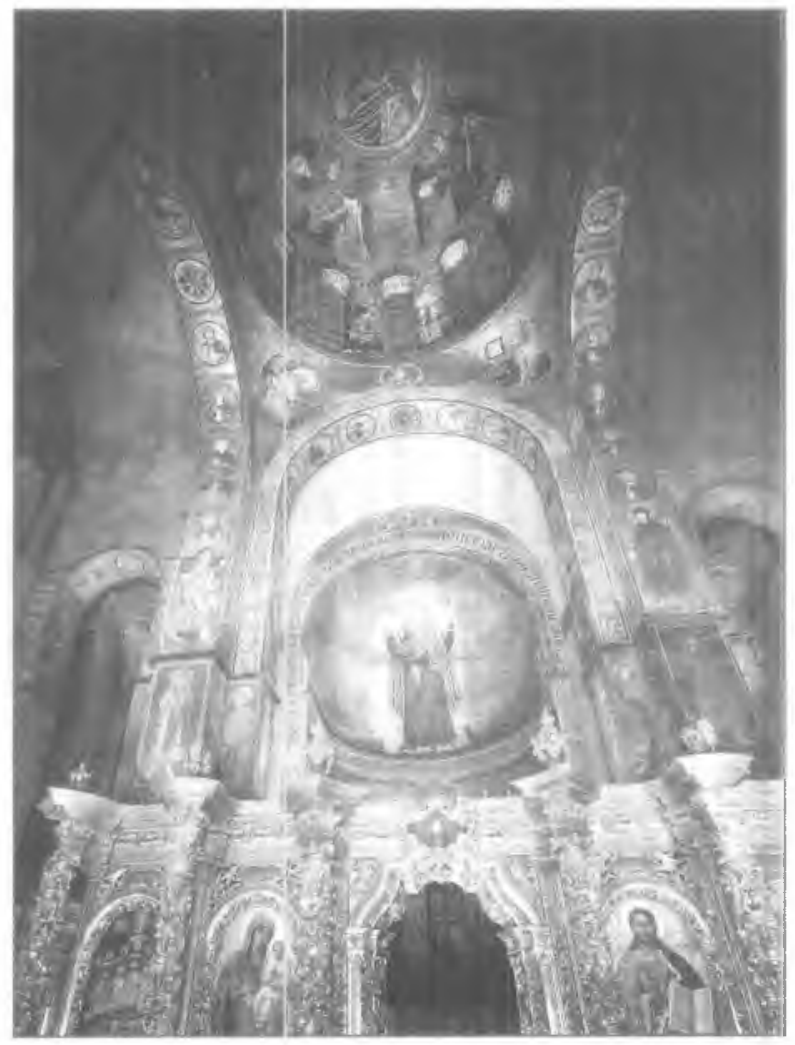

1. Mozaiki w katedrze św. Sofii w Kijowie - Deesis, Matka Boska Oranta, Zwiastowanie (wedlug G. N. Logwyn, Sofija Kiïska, Kijów 1971). 


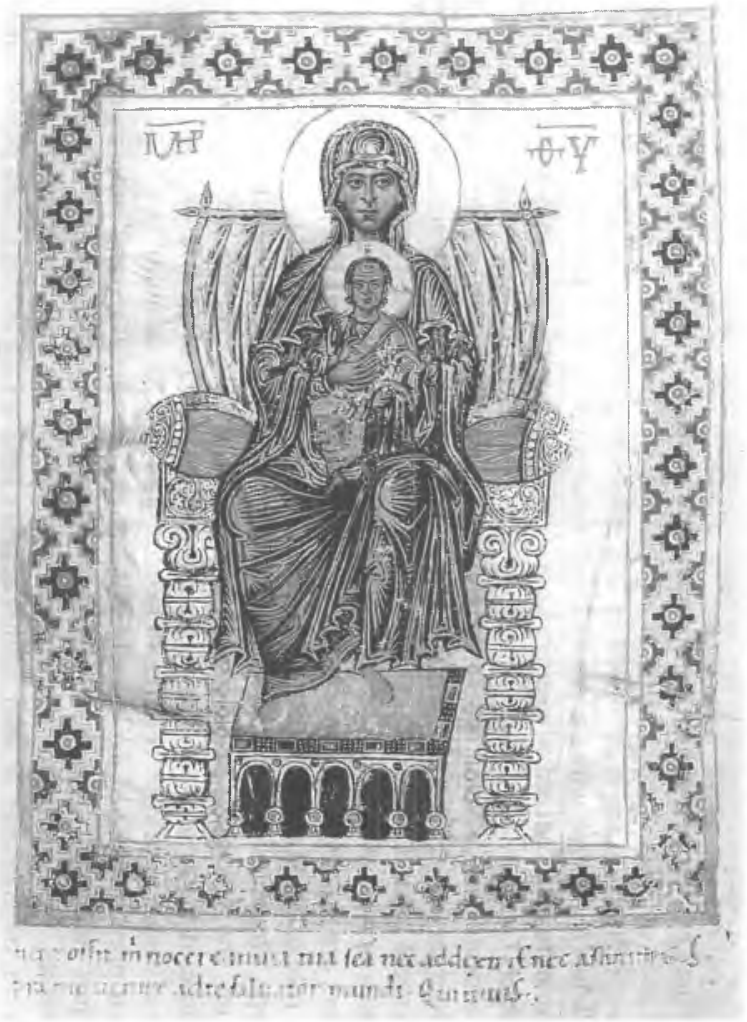

$\underset{\perp}{\infty}$

2. Tronująca Matka Boska z Emmanuelem typ

Nikipoja, miniatura w kodeksie Gertrudy, fol. 41r (według M. Smorąg Różycka, Bizantyńsko-ruskie miniatury kodeksu Gertrudy, Kraków 2003). 


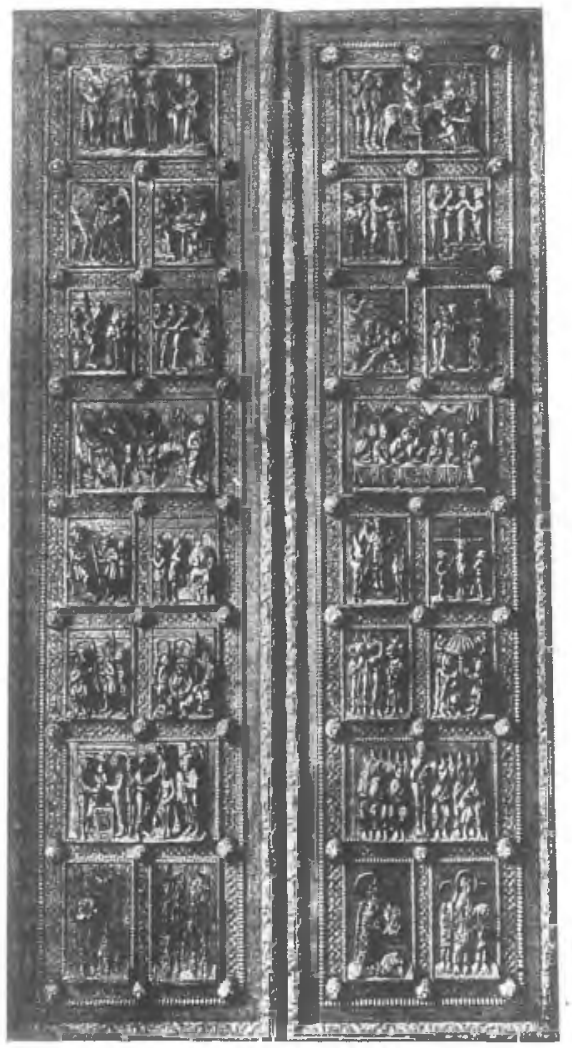

3. Drzwi drewniane z kościoła Sankta Maria im Kapitol w Kolonii, ok. 1050 r. (według H. Jantzen, Ottonische Kunst, München 1947). 


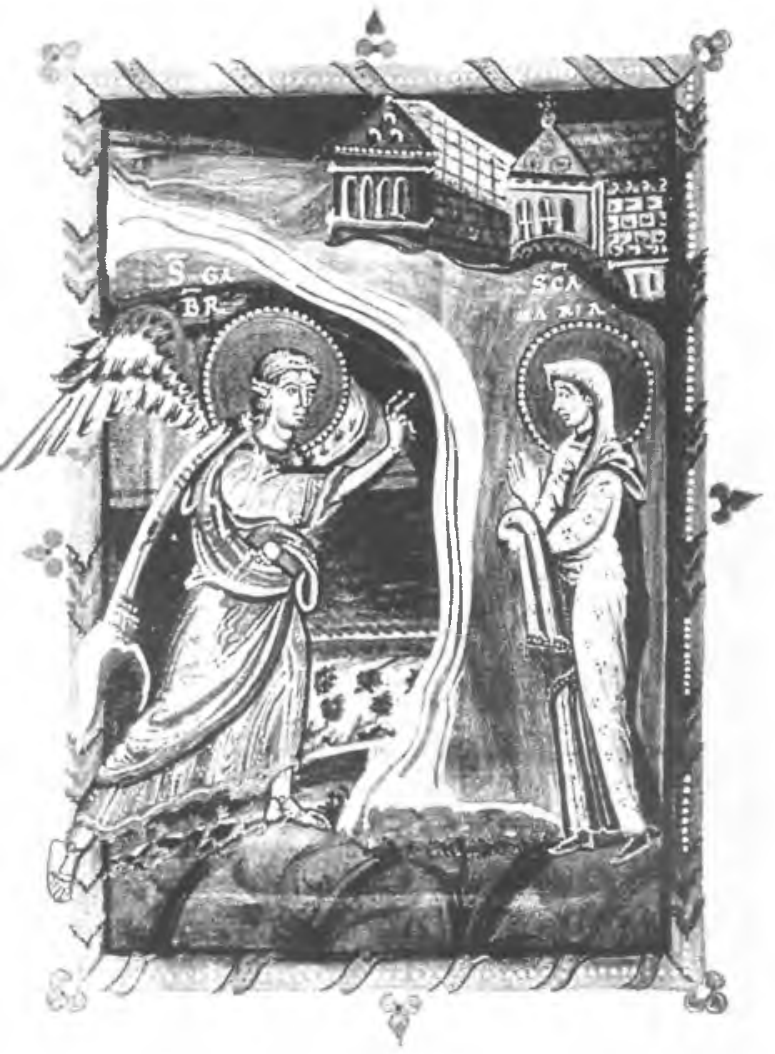

4. Zwiastowanie, miniatura $\mathrm{z}$ Ewangeliarza opatki Nitdy z Meschede, ok. 1020 r. (według P. Bloch, H. Schnitzler, Die Ottonische Kölner Malerschule, Bd I, Düsseldorf 1967). 


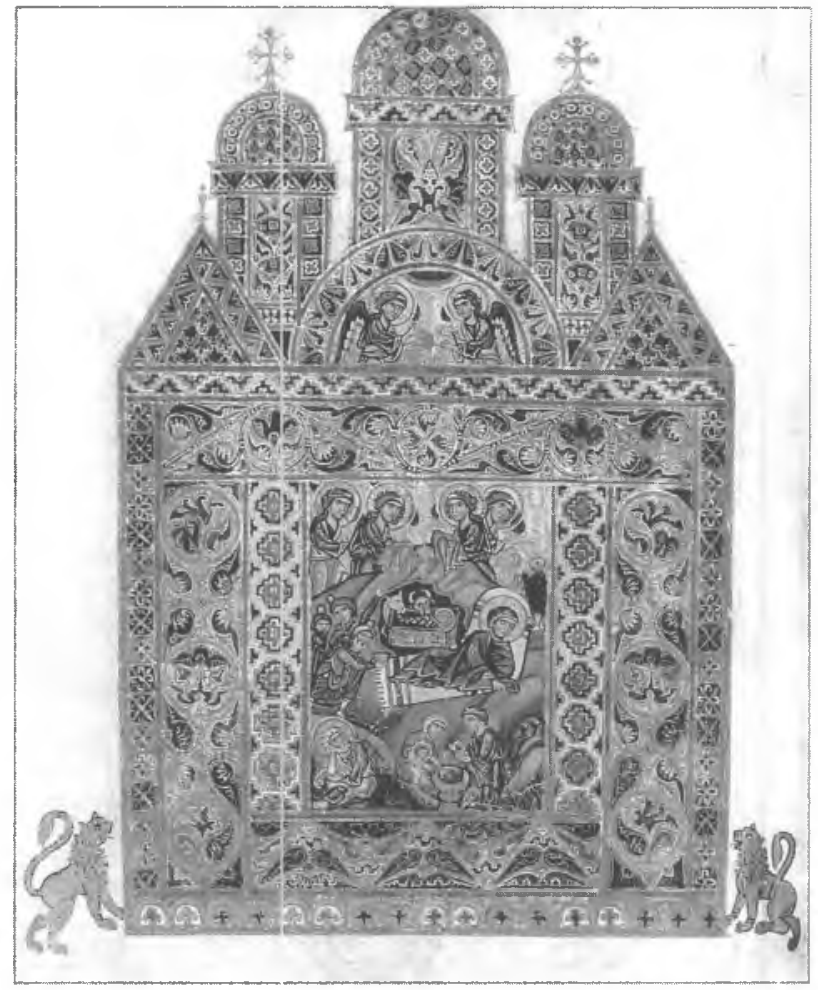

5. Boże Narodzenie, miniatura w Kodeksie Gertrudy, fol. 9 v (według M. Smorąg Różycka, Bizantyńsko-ruskie miniatury kodeksu Gertrudy, Kraków 2003). 


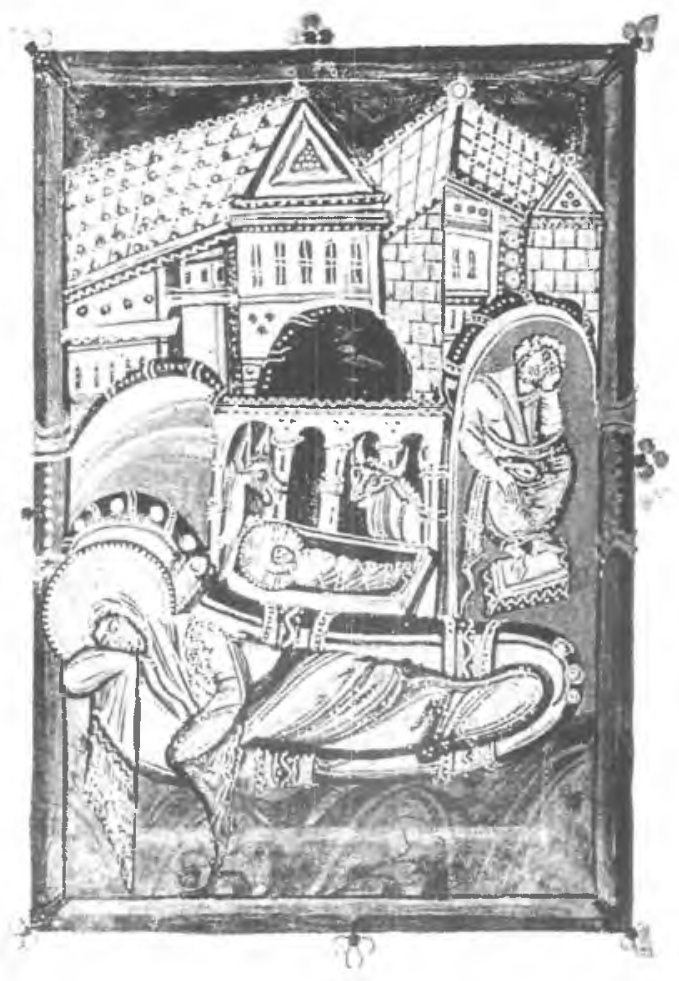

$\infty$

6. Boże Narodzenie, miniatura z Ewangeliarza opatki Nitdy z Meschede, ok. 1020 r. (według P. Bloch, H. Schnitzler, Die Ottonische Kölner Malerschule, Bd I, Düsseldorf 


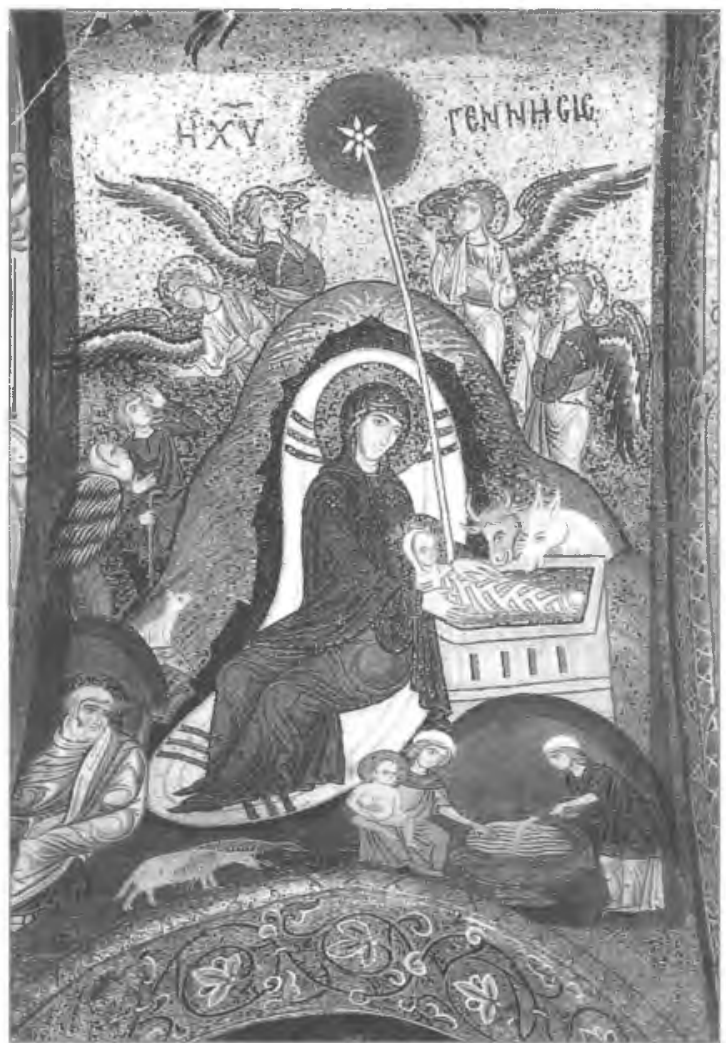

7. Boże Narodzenie, mozaika w kościele Martorana w Palermo, XII w. (według O. Demus, The Mosaics of Norman Sicily, London 1949). 


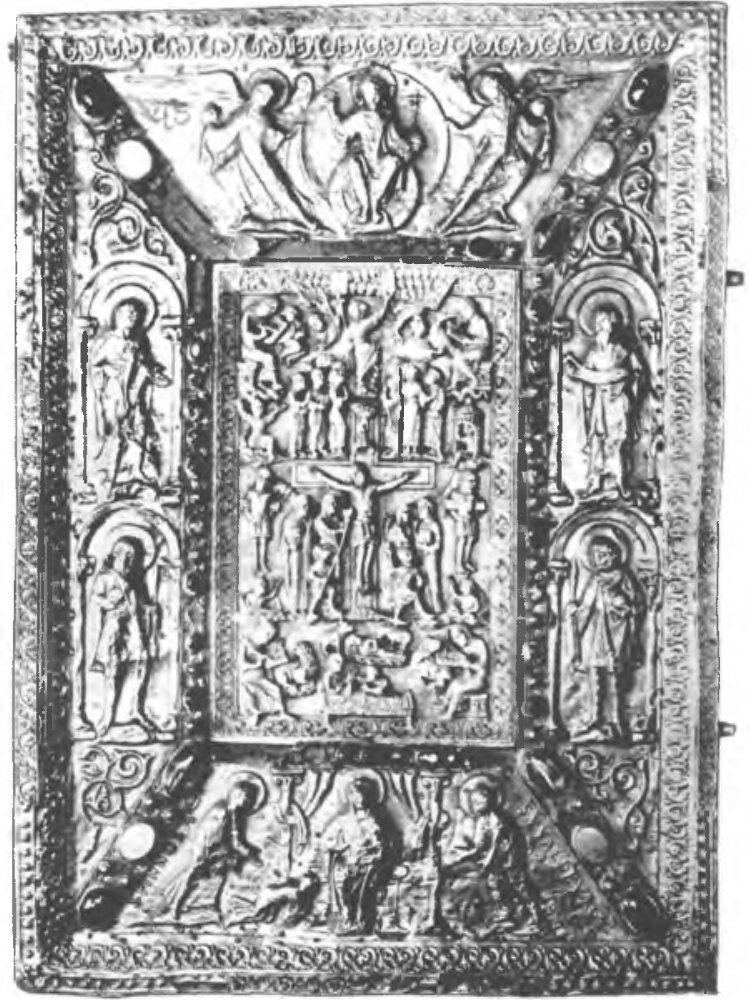

8. Oprawa ze złota i kości słoniowej fundacji opatki Thephanu, Skarbiec katedry w Essen (według H. Jantzen, Ottonische Kunst, München 1947). 